\title{
SARS-CoV-2: sewage surveillance as an early warning system and challenges in developing countries
}

\author{
Deepak Panchal ${ }^{1,2} \cdot$ Om Prakash ${ }^{2} \cdot$ Prakash Bobde $^{2,3} \cdot$ Sukdeb Pal ${ }^{1,2}$ \\ Received: 6 November 2020 / Accepted: 22 February 2021 / Published online: 17 March 2021 \\ (C) The Author(s), under exclusive licence to Springer-Verlag GmbH Germany, part of Springer Nature 2021
}

\begin{abstract}
Transmission of novel coronavirus (SARS-CoV-2) in humans happens either through airway exposure to respiratory droplets from an infected patient or by touching the virus contaminated surface or objects (fomites). Presence of SARS-CoV-2 in human feces and its passage to sewage system is an emerging concern for public health. Pieces of evidence of the occurrence of viral RNA in feces and municipal wastewater (sewage) systems have not only warned reinforcing the treatment facilities but also suggest that these systems can be monitored to get epidemiological data for checking trend of COVID-19 infection in the community. This review summarizes the occurrence and persistence of novel coronavirus in sewage with an emphasis on the possible water environment contamination. Monitoring of novel coronavirus (SARS-CoV-2) via sewage-based epidemiology could deliver promising information regarding rate of infection providing a valid and complementary tool for tracking and diagnosing COVID-19 across communities. Tracking the sewage systems could act as an early warning tool for alerting the public health authorities for necessary actions. Given the impracticality of testing every citizen with limited diagnostic resources, it is imperative that sewage-based epidemiology can be tested as an early warning system. The need for the development of robust sampling strategies and subsequent detection methodologies and challenges for developing countries are also discussed.
\end{abstract}

Keywords SARS-CoV-2 $\cdot$ Coronavirus $\cdot$ Surveillance $\cdot$ COVID-19 $\cdot$ Sewage $\cdot$ Transmission

\section{Introduction}

The ongoing emergence of novel Severe Acute Respiratory Syndrome Coronavirus 2 (SARS-CoV-2) has aroused widespread fear and created a threat to global health security (Wuhan Municipal Health Commission 2020). The viral outbreak (COVID-19, name given by World Health Organization, WHO) has infected more than 100 million confirmed cases with $\sim 2.2$ million deaths across the world (as of January 27, 2021) (WHO 2021). Similarities with Severe Acute Respiratory Syndrome Coronavirus (SARS-CoV-

Responsible Editor: Philipp Gariguess

Sukdeb Pal

s_pal@neeri.res.in

1 Academy of Scientific and Innovative Research (AcSIR), Ghaziabad 201002, India

2 Wastewater Technology Division, CSIR-National Environmental Engineering Research Institute, Nagpur 440020, India

3 Department of Research \& Development, University of Petroleum \& Energy Studies, Dehradun, Uttarakhand 248007, India
2003) and Middle East Syndrome Coronavirus (MERSCoV-2012) in respect to their transmission to humans, SARS-CoV-2 has emerged as the third extremely pathogenic virus in last two decades (Otter et al. 2016; Kampf et al. 2020). Previously identified coronaviruses have been reported to persist on surfaces like metal, glass or plastic etc. ranging $8 \mathrm{~h}$ to 9 days (Kampf et al. 2020; WHO 2020a). Similarly, SARS$\mathrm{CoV}-2$ can also persist on many surfaces increasing the chance of its further transmission through these contaminated fomites (van Doremalen et al. 2020; Al-Tawfiq et al. 2014; Kampf et al. 2020). For the time being, the information regarding occurrence and survival of SARS-CoV-2 virus in water environments is unclear. However, the presence of viral ribonucleic acid (RNA) in the feces or rectal swab of infected patients has demanded rigorous quantitative testing for the occurrence and survival of SARS-CoV-2 virus in water environments (Zhang et al. 2020a; Xiao et al. 2020). Many COVID-19 infected personnel have been diagnosed with no apparent symptoms. These COVID-positive but asymptomatic patients can also contribute toward further transmission during the asymptomatic period (Zhou et al. 2020; Bai et al. 2020). Both asymptomatic as well as symptomatic patients 
can shed viruses via feces that ultimately go to sewage treatment plants (STPs) (Haramoto et al. 2020a, 2020b). Limited knowledge of SARS-COV-2 viability, its presence in excreta, and a subsequent possible pathway to sewage systems can eventually lead to unwarranted spread. Therefore, behavior and persistence of this new virus in the water cycle need to be understood to stop further spreading of the infection.

Respiratory issues and diarrhea are some indications for COVID-19 infection observed both in hospital and family/ community settings (Chan et al. 2020). WHO has suggested frequent and proper hygiene practices. Disinfection of public facilities and proven practices of taking measures like regular hand washing etc. could prevent further transmission (WHO 2020b). Such efforts can also control the incidence of many other infectious diseases and save millions of lives each year. Advanced biocidal reagents like sodium hypochlorite, benzalkonium chloride, alcohols, and hydrogen peroxide are being used for disinfection in healthcare settings. However, the prolonged incubation time of virus in human and asymptomatic nature of patients have allowed the virus to be clinically undetected that certainly helped the virus spread and paved its way to sewage systems (Wu et al. 2020a). The clinical observations of viral SARS-CoV-2 RNA in feces have implied that sewage of affected zones might contain the virus (Xiao et al. 2020; Gu et al. 2020; Chen et al. 2020a). Detection of viral RNA in wastewater treatment systems has indicated the potential of sewage surveillance as an early warning system for tracking contagious diseases (Kitajima et al. 2020; Wu et al. 2020b). Sewage-based epidemiology is generally known as wastewater-based epidemiology (WBE) that helps tracking and understanding the incidence of viruses in a given sewage/wastewater treatment plant receiving sewage/effluent from communities that may contain viruses or its fragments being shed along with feces from symptomatic and asymptomatic individuals (Sinclair et al. 2008; Sims and Kasprzyk-Hordern 2020; Xagoraraki and O'Brien 2020). Investigation through sewage-based epidemiology holds a potential to be used as a substantial information tool for surveillance of a large population that may be under the threat of COVID-19 pandemic (Hart and Halden 2020). Sewage collection is relatively inexpensive, easy, and can be used to monitor different levels in population aggregation. Therefore, sewagesurveillance can offer a cost-effective and real-time analysis to reflect the community's health independent of symptomaticbased clinical reporting (Thompson et al. 2020). However, discrepancies in the detection of SARS-CoV-2 have been observed in sewage samples due to the analytical sensitivity of protocols used as well as the false positive observations in low concentrated clinical samples (Randazzo et al. 2020; Jung et al. 2020; Vogels et al. 2020). In order to avoid producing conflicting data, such approaches essentially require development of robust sampling and detection strategies.

A critical issue which is not being paid much attention is the development of antimicrobial resistance (AMR) in sewage during this pandemic. With no or limited proven therapy for COVID-19, people are more likely to use antibiotics indiscriminately for treatment and prevention of presumed infections. This is of huge concern especially in developing countries where medications can be bought over the counter without prescriptions. As per WHO, there is very limited data available on AMR in Africa due to lack of testing and surveillance capability (Egyir et al. 2020). In addition, continuous use of hand sanitizers, soaps, alcohol-based sanitizers, floor cleaners, and other essential disinfectants which is being discharged with water could also exacerbate AMR in sewage and can pose irreversible changes to available water resources.

In India, the first case was reported on January 30, 2020 which has now proliferated to almost all states of the country with a total of $\sim 10.7$ million confirmed cases and $\sim 0.154$ million deaths as of January 27, 2021 (WHO 2021). In response to the outbreak of this pandemic, Government of India declared a series of nationwide lockdowns to minimize the rate of COVID transmission. The concern of transmission via water is enormous in a country like India, where currently $17.7 \%$ of the total human population on earth lives and millions are still deprived from access to clean drinking water. In addition to that, open defecation (OD) is one of the major issues that have historically been most prevalent among lowincome countries. In such cases, unhygienic practices may add more complications and increase the chances of contamination of water environments. Thus, there is a great threat to public health due to possible fecal-oral route of disease transmission (Hindson 2020; Heller et al. 2020). However, population without access to toilets has been reduced significantly by an estimated 450 million people from 568 million in India (WASH 2020).

Developing countries still lack appropriate infrastructures (at least biosafety levels-II) needed for the detection of SARS$\mathrm{CoV}-2$ that comply with WHO guidelines. Moreover, fragile health care systems, inadequate existing medical diagnostic methods, and lack of medical tools during the outbreak can exponentially increase the number of infected people (UNDP 2020). Available studies on the detection of coronaviruses in wastewater are limited to the developed countries and mostly written in European and the United States' perspective. Till now, only a few studies for detection of genetic material of SARS-CoV-2 in sewage have been reported in India, but again infectivity and threat from excreted viral material remained unclear (Kumar et al. 2020a; Arora et al. 2020). Inadequate or no operational wastewater treatment facilities in developing counties can lead to an eventual transmission of viruses to the surface water environment. Therefore, it is urgent to determine the current status of the infection in communities to keep a check on the infection trend. The entrance, survival, transmission, and fate of SARS-CoV-2 in sewage and threat of contamination of water resources are of utmost importance in developing countries like India. 
Herein, we review the transmission, survival, and chance of infection by SARS-CoV-2 in water environment and potential of sewage surveillance as an early warning system for spread of infections. Available treatment options as prescribed by regulatory or advisory agencies and the need to develop robust sampling strategies and subsequent detection methodologies to suitable for wastewater samples are highlighted. In densely populated developing countries like India with relaxed surface water quality criteria in terms of fecal coliform bacteria and open defecation practices, there is a huge challenge to stop pathogenic viruses like SARS-CoV-2 from entering into and ensure removal from water cycle. The vulnerability of densely populated developing countries to unwarranted spread of COVID-19 through indirect routes and future needs are also discussed.

\section{Water cycle cascade: transmission, survival, and chance of infection}

\section{Transmission}

Coronaviruses may be transmitted to municipal sewage through several sources, such as vomit, sputum and handwashing (Han et al. 2020; Sung et al. 2016; Haagmans et al. 2014). While there are reports on viral shedding of coronavirus (SARS-CoV, MERS, and SARS-CoV-2) in urine of infected individuals (Xu et al. 2005; Drosten et al. 2013; Nomoto et al. 2020), shedding of the viral RNA in feces of infected individuals has also been reported extensively as the main route of transmission (Chen et al. 2020b; Ling et al. 2020; Zhang et al. 2020a). Figure 1 elucidates the possibilities of transmission of coronaviruses in water originating from community, hospital settings, and aerosolization from weak plumbing system.

Patients infected with coronavirus (SARS, MERS) may experience watery diarrhea $(20.3 \%$ out of 138$)$ during the course of illness (Lee et al. 2003). Similarly, 2-10\% of confirmed cases of COVID-19 disease were observed to have diarrhea as one of the symptoms of infection (Wang et al. 2020a; Huang et al. 2020; Chen et al. 2020c). While duration of shedding is still unclear, a few studies reported that viral RNA can be detected in the feces from 1-25 days after onset of the gastrointestinal infection (Amirian 2020). Detection of viral RNA of SARS-CoV-2 in duodenal, gastric, rectal epithelia, and feces of infected individual substantiates the concern for waterborne transmission (Zhang et al. 2020b; Xiao et al. 2020). Furthermore, asymptomatic person can easily shed the viral load in stool that may spread in sewage as well as in surface water systems (Núñez-Delgado 2020). It is noteworthy that a positive result for feces may be due to the presence of viral RNA only and not because of viable viral cells. However, a few studies that used viral nucleocapsid staining and electron microscopy approaches suggest that fecal samples can also contain viable viruses (Zhang et al. 2020c). There is evidence that support that in about $10 \%$ of COVID19 patients, viral RNA was still detected in the feces even after no viral RNA was found in respiratory tract samples suggesting that GI infections may occur first in a subset of coronavirus infections (Xiao et al. 2020). It can therefore be deduced that staff handling sewage may be exposed to these pathogens days before an outbreak is reported. Occurrence of viral RNA in sewage systems has put the workers at sewage treatment plants (STPs) under the possible threat of exposure within the STPs through aerosol inhalation or direct contact with infectious viral particles.

\section{Survival}

Nonenveloped enteric viruses, like adenoviruses, polio viruses, enteroviruses, noroviruses, and rotaviruses, are transmitted primarily through the fecal-oral route (Ye et al. 2016). Thus, majority of the available reports on the occurrence of viruses in sewage are focused on these nonenveloped enteric viruses (Katayama et al. 2008; Fumian et al. 2010). Ye et al. (2016) However, existence of enveloped viruses, like coronaviruses, in water environment may differ greatly due to different survival and partitioning behavior in water (Ye et al. 2016; Arbely et al. 2006). Fate of these viruses in wastewater mainly depends on their ability to survive in the extreme wastewater environment and their removal during different stages of wastewater treatment. Various intrinsic or extrinsic factors such as viral structure, characteristics/composition of the water environment, temperature, $\mathrm{pH}$, antagonistic microorganisms, etc. can influence the survival of coronaviruses in wastewater (Naddeo and Liu 2019). Though human enveloped viruses are presumed to undergo rapid inactivation in the water environment (Kampf et al. 2020; Ye et al. 2016), reports of these viruses in feces and wastewater suggest that they may survive longer than presumed. A few studies have indicated the occurrence of live SARS-CoV-2 in stool samples and its cultivation has also been reported (Wang et al. 2020c; Zhang et al. 2020c). There are evidences in support that surrogate coronaviruses could remain infectious in water contaminated with feces for days to weeks (WHO 2020a; Casanova et al. 2009). Given the possible active gastrointestinal replication of SARS-CoV-2 and the presence of viral RNA in faces, urine, and sewage samples, viral cells could be present in sewage treatment systems, regardless of its concentration and viability which remains to be confirmed (Foladori et al. 2020). Other known coronaviruses have been observed to be infectious in natural environmental waters, reagent grade waters, and water contaminated with human fecal waste (sewage) for periods of weeks (Casanova et al. 2009). SARS-CoV has been found to be able to survive for 2 days in dechlorinated tap water, domestic, and hospital wastewater; 17 days in urine; and 3 days 


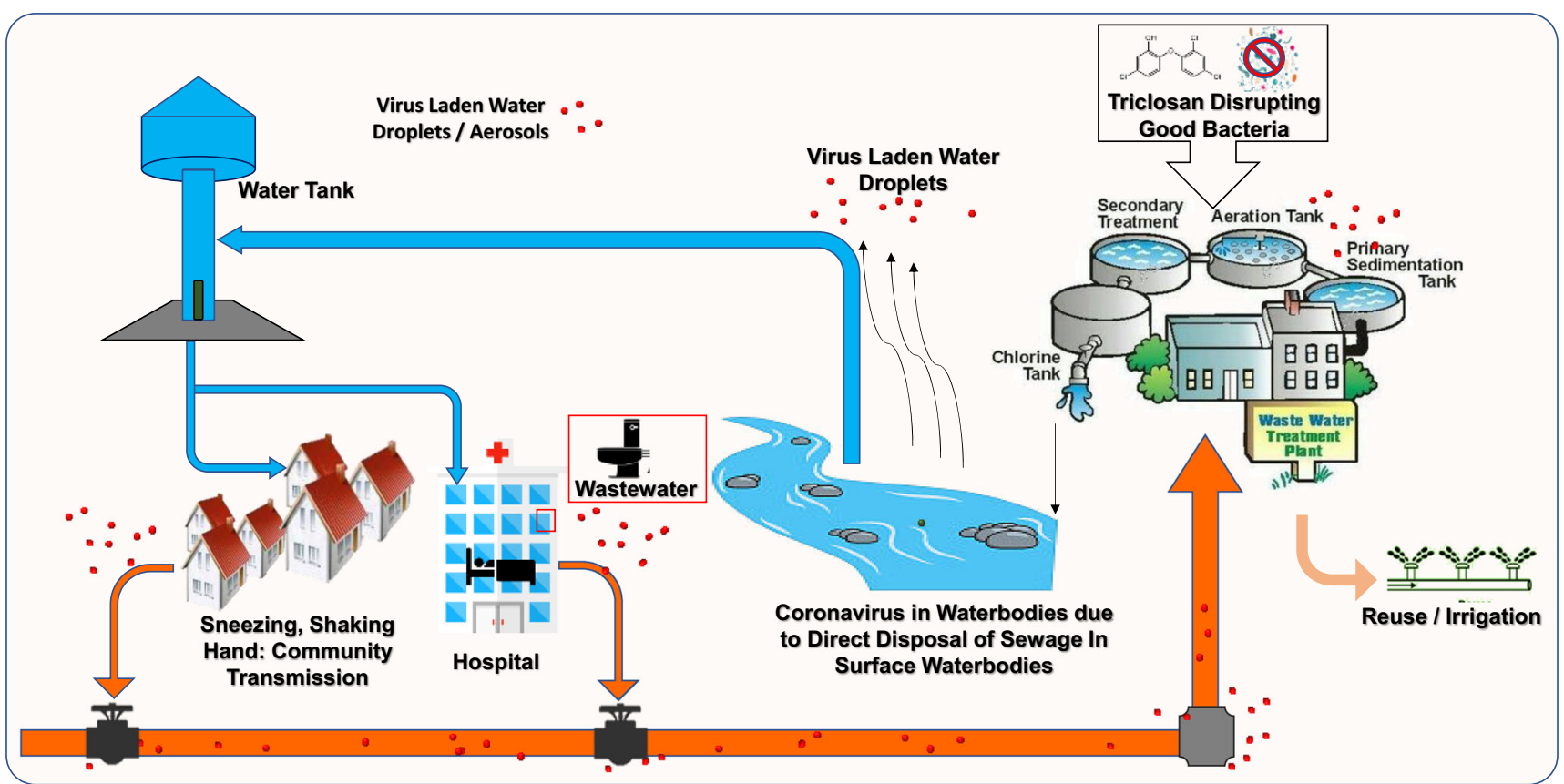

Fig. 1 Occurrence, transmission, fate of Coronavirus in community

in feces at $20{ }^{\circ} \mathrm{C}$. At lower temperature $\left(4{ }^{\circ} \mathrm{C}\right)$, SARS-CoV persists for at least 17 days in feces or urine and 14 days in sewage (Wang et al. 2005). These findings suggest that in colder regions, coronaviruses may survive longer in wastewater as compared to tropical regions. The decreasing survival of the virus with increase in temperature could be attributed to denaturation of proteins and nucleic acids, and enhanced activity of extracellular enzymes (Aquino de Carvalho et al. 2017). Though there is no direct information about the effect of $\mathrm{pH}$ on the survival of coronaviruses, stability of the surrogates for coronaviruses such as the mouse hepatitis virus (MHV) and transmissible gastroenteritis virus (TGEV) indicates the possible impact of $\mathrm{pH}$ on coronaviruses. While MHV is considered to be stable in the $\mathrm{pH}$ range of 5-7.4 at $37{ }^{\circ} \mathrm{C}$ and $3-10$ at $4{ }^{\circ} \mathrm{C}$ (Casanova et al. 2009; Daniel and Talbot 1987), the stable $\mathrm{pH}$ range for TGEV is $5-7$ at $37^{\circ} \mathrm{C}$ and 5-8 at $4{ }^{\circ} \mathrm{C}$. In acidic $\mathrm{pH}$, reversible acid denaturation of RNA through protonation of GC base pairs and consequent formation of Hoogsteen base pairing (Mariani et al. 2018) disturbs the viral stability. Also, at lower $\mathrm{pH}$, viral adsorption on suspended particulates increases and thus influences the viral stability (Schaub et al. 2017).

\section{Chance of infection}

Inactivation of emerging viruses such as SARS-CoV, MERS$\mathrm{CoV}$, and other coronaviruses using common biocidal agent varied from $2 \mathrm{~h}$ to 9 days depending on different inanimate surfaces (Kampf et al. 2020; WHO 2020a). This is enough time to infect people coming in contact with the contaminated surfaces. Coronaviruses can also remain infectious for long periods (days) in sewage and in drinking water. Therefore, water contaminated by coronaviruses may act as a potential fomite if aerosols are generated. Moreover, coronavirus can creep into drinking water distribution network due to inadequate disinfection process. In distribution network, biofilmforming colonizing bacteria can help maintaining its viral stability and eventually it may find its way to individual homes. Easy aerosolization due to weak plumbing system can further add more threat to public health. It has been observed that turbulent and unsteady flow of wastewater due to random discharge induces pressure fluctuations in plumbing systems which in turn can compromise the fragility of water seals. There are very high chances for deposition of aerosols contaminated with virus on the fomites and direct contact may be a major route of infection (Amoah et al. 2020). Such defects were identified in 50-storey building leading to a superspreading event of SARS in 2003 that killed 42 people and caused 342 confirmed cases (WHO 2003). It was further tested that the turbulence created by toilet discharge is sufficient to aerosolize the 'virus laden droplets' (as shown in Fig. 1) which can potentially infect the surfaces in living area (Gormley et al. 2017). Thus, there are chances of crossinfection in healthcare centers due to weak plumbing network and transmission of viral load in wastewater systems. Using old buildings and other settings for quarantining greater numbers of infected people is also a big concern because of the interconnectedness of the whole plumbing system (Gormley et al. 2020). Aerosols generated from such networks are actually microparticles laden with viruses that may stay in ambient environment. A little movement of air circulation may spread and can infect everyone in a room (Liu et al. 2020; Zhang 
2020). These aerosols, laden with viruses, may also infect sewage treatment plants workers through aerosol inhalation or direct contact with surfaces of particles contaminated with viral cells. Currently, there is no experimental data available on the formation and rate of formation of such aerosols laden with SARS-CoV-2 during sewage treatment processes. In a study, the risk of exposure was highlighted using $E$. coli as a standard microbial exposure and it was assessed that the risk of exposure associated with the SARS-CoV-2 is 30 times higher for wastewater workers (Zaneti et al. 2020). Weak sewage treatment infrastructures and untreated sewage disposal practices in receiving waterbodies may further increase the chances of infection in developing countries.

\section{Sewage surveillance as an early warning system}

The concept of sewage-based epidemiology aims to use sewage analysis as an early warning system for disease outbreak (Xagoraraki and O'Brien 2020). This is based upon the detection of chemical/biological signature compounds/entities from sewage samples and interpretation of the analytical results much before the onset of illness/outbreak. These compounds are biomarkers that are specific to human excretions such as metabolites that formed endogenously in response to onset of any particular disease. Detection of these biomarkers can be geographically linked to whole population served by those sewage treatment systems. Thus, sewage-based epidemiology can be used as fingerprint of the community's lifestyle and health status (Kasprzyk-Hordern et al. 2014). Sewage surveillance has been previously used as an early warning system for tracking drugs or pharma consumption, poliovirus and infectious disease monitoring, etc. (Nakamura et al. 2015; Sims and Kasprzyk-Hordern 2020). Since viral RNA of SARS-CoV-2 can be detected in feces, and subsequently in sewage, weeks before the onset of illness, extrapolation of viral load together with the other relevant information could help in predicting the trend of infection in a community. The detection of SARSCoV-2 viral RNA in sewage has gained much attention and has been validated for early warning in developed as well as in developing countries (Arora et al. 2020; Bar-or et al. 2020; Bogler et al. 2020; Gonzalez et al. 2020; Haramoto et al. 2020a, 2020b; Mao et al. 2020a, 2020c; Polo et al. 2020; Street et al. 2020). Moreover, data from sewage-based epidemiology can help in estimating the realistic number of virusinfected people in the community covering pre-symptomatic and asymptomatic individuals that may remain unobserved during clinical observations (Tang et al. 2020). Regular investigation of sewage could also be helpful in observing current status and additional SARS-CoV-2 infection outbreak or any other future viral epidemics (Daughton 2018). When individual and frequent testing becomes difficult in a populated country, such aggregated information could be useful for monitoring the level of the outbreak in containment zones.

\section{Key indicators of sewage-based epidemiology}

It is crucial to choose markers of interest from wide-ranging panel that could provide information on pathogenic organisms, physiological changes, biological response, and antimicrobial resistance. Detection through biomarkers is carried out by mass spectrometry (MS) or ELISA which can provide better detection limit with accuracy and validation in comparison to standard PCR measurements. Various pharmaceuticals used to treat many infectious diseases consequently end up in sewage in either in metabolized or un-metabolized forms. An increment in load of various drugs such as antibiotics including ciprofloxacin and erythromycin in sewage typically observed in winters and can be attributed to the respiratory infections (Coutu et al. 2013; Golovko et al. 2014). Similar to these pharmaceuticals, biological entities such as residual RNA/DNA/metabolites related to pathogens from sewage/ wastewater could also indicate occurrence and rate of infection of particular disease circulating in the population (O'Brien and Xagoraraki 2019). Thus, assessment of elevated levels of these markers in sewage can be used for early warnings in disease tracking. There are various potential chemicals as well as biological key indicators that have been used previously for monitoring infectious diseases circulating at community level through wastewater (Table 1).

Currently, genetic material RNA is the only established primers/probe (nucleocapsid and envelope protein genes) used as biomarkers for detection of SARS-CoV-2. Therefore, investigation of such biomarkers linked to SARS$\mathrm{CoV}-2$ could be used to track the spread of virus, if allied with effective response system.

\section{New paradigm for real assessment of COVID-19}

Detection of viral (SARS-CoV-2) RNA in various samples of excreta such as feces and rectal swabs from infected patients is possible within 3 weeks from the date of sample collection as the median duration of survival of virus out of the body such as in stool is 22 days. This is significantly higher than that found in respiratory airways and serum samples (Zheng et al. 2020). Over one-half of the fecal samples collected from hospitalized patients were found positive for SARS-CoV-2 infection, including cases with and without gastrointestinal symptoms (Lin et al. 2020; Xiao et al. 2020; Wang et al. 2020c). Study conducted by Xiao et al. (2020) revealed that over $20 \%$ of the infected individual found positive in feces; however, their respiratory samples produced negative results. Another investigation revealed that patients were persistently given positive test on rectal swabs samples even after their negative nasopharyngeal tests (Xu et al. 2020). This suggests that even 
Table 1 Potential biomarker used for monitoring infectious disease

\begin{tabular}{|c|c|c|c|}
\hline Biomarker & Example & Indicator of & Reference \\
\hline \multirow[t]{11}{*}{$\begin{array}{l}\text { Chemical: } \\
\text { Drug and metabolites }\end{array}$} & $\begin{array}{l}\text { Azithromycin } \\
\text { n-Demethyl azithromycin }\end{array}$ & $\begin{array}{l}\text { intestinal infections and middle } \\
\text { ear infections, Pneumonia, } \\
\text { strep throat and }\end{array}$ & Senta et al. 2019 \\
\hline & Ciprofloxacin & $\begin{array}{l}\text { Respiratory tract and skin } \\
\text { infections, gastroenteritis }\end{array}$ & Guerra et al. 2014 \\
\hline & $\begin{array}{l}\text { Clarithromycin } \\
n \text {-Demethyl clarithromycin }\end{array}$ & $\begin{array}{l}\text { skin infections, pneumonia, } \\
\text { and Lyme disease. }\end{array}$ & Senta et al. 2019 \\
\hline & $\begin{array}{l}\text { Sulfamethoxazole } \\
n \text {-Acetyl sulfamethoxazole }\end{array}$ & $\begin{array}{l}\text { Bronchitis and Urinary tract } \\
\text { infections }\end{array}$ & $\begin{array}{l}\text { Hijosa-Valsero et al. 2011; } \\
\text { Guerra et al. } 2014\end{array}$ \\
\hline & Erythromycin & Respiratory tract infections & Kasprzyk-Hordern et al. 2009 \\
\hline & $\begin{array}{l}\text { Oseltamivir phosphate } \\
\text { Oseltamivir carboxylate } \\
\text { Zanamivir }\end{array}$ & Flu virus (influenza) & $\begin{array}{l}\text { Leknes et al. } 2012 \\
\text { TAKANAMI et al. } 2012\end{array}$ \\
\hline & Clotrimazole & Skin and vaginal infections & Huang et al. 2010 \\
\hline & Acetaminophen & Painkiller & Guerra et al. 2014 \\
\hline & Ibuprofen & & Guerra et al. 2014 \\
\hline & Interlukin-8 (IL-8) & $\begin{array}{l}\text { Inflammation in urinary } \\
\text { tract infections }\end{array}$ & $\begin{array}{l}\text { Taha et al. 2003; Rice and } \\
\text { Kasprzyk-Hordern } 2019\end{array}$ \\
\hline & C-reactive protein (CRP) & Inflammation & Stuveling et al. 2003 \\
\hline \multirow{6}{*}{$\begin{array}{l}\text { Biological: } \\
\text { Pathogenic bacterial DNA, } \\
\text { viral RNA/DNA and } \\
\text { Antibiotic resistant genes }\end{array}$} & Klebsiella pneumoniae & $\begin{array}{l}\text { UTI, Pneumonia, bacteremia } \\
\text { and endophthalmitis }\end{array}$ & Shannon et al. 2007) \\
\hline & Norovirus (GI) & Gastroenteritis & Hellmér et al. 2014 \\
\hline & Zika & Mild infection, microcephaly & Gourinat et al. 2015 \\
\hline & mecA & Methicillin resistance & Börjesson et al. 2009 \\
\hline & ermB & Erythromycin resistance & Wang et al. 2015 \\
\hline & tet $W$ & Tetracycline resistance & Wang et al. 2015 \\
\hline
\end{tabular}

after negative test for virus in the respiratory tract, they may be actively replicating in the gastrointestinal tract. Therefore, collection of sewage sample could be used as a bundle of information leading to the true picture of infection. A few studies have successfully supported sewage-based epidemiology as an early warning system. For example, samples collected from wastewater at Amsterdam airport were analyzed using quantitative real-time reverse-transcription polymerase chain reaction (RT-PCR) methodology and the presence of viral RNA was detected within the $6^{\text {th }}$ day of first reported case of COVID-19 disease (Lodder and de Roda Husman 2020). Also, domestic wastewater samples were tested positive for viral RNA in Tilburg, Netherlands, within a week of first detection of COVID-19 patient (Medema et al. 2020a). Interestingly, sewage samples of Amersfoort (Netherlands) gave positive qRT-PCR test for SARS-CoV-2 6 days before the first case was reported (Medema et al. 2020a) A median range (171 to 1090) of infected persons was found to be in good agreement with clinical observations using the concept of sewage surveillance (Ahmed et al. 2020). Indeed, investigating sewage/wastewater samples could be used as a sensitive epidemiological tool and serve as an early warning system. Prolonged incubation period of virus in gastrointestinal tract and survival in stool also authenticate sewage surveillance as a tool for diagnostic and tracking method for COVID-19 infection across communities.

It takes around 14 days for symptom to be evident in any SARC-CoV-2 infected person (CDC 2020a; Al-Tawfiq 2020). A large percentage of people is clinically diagnosed positive for SARS-CoV-2 that remain asymptomatic (Lai et al. 2020; Rothe et al. 2020). However, clinical diagnosis for SARS-CoV-2 is usually recommended only if the symptoms persist for long duration. On the contrary, even with mild or no symptoms, detection of viral RNA in sewage is highly possible within a week of infection (Medema et al. 2020a). This showed the advantages and effectiveness of sewagebased epidemiology as an early detection tool for the disease. While sewage-based epidemiology can predict CoV-2 outbreaks within a week, symptoms-based epidemiology (clinical diagnostics) needs at least 2 weeks for detection of $\mathrm{CoV}-2$ outbreak. Higher titer values of SARS-CoV-2 in sewage than clinically confirmed cases elucidate the underestimation of positive but asymptomatic cases by the latter method (Wu et al. 2020b). Therefore, sewage investigation may also give an idea about extent of possible spread of novel coronavirus in the surrounding area. Thus, this approach can substantially 
improve the prediction efficiency of infection dynamics and help alerting public health authorities when an area becomes hotspot much before the population is diagnosed properly or have mild symptoms. In the absence of proper viral diagnostic facilities, monitoring sewer system could be used for screening the whole area and act as a mirror of the infected population.

\section{Challenges in sewage-based epidemiology}

\section{Complex sample matrix}

Low concentration of viral load in sewage, target nonspecificity due to interference of chemical micro-pollutants in the sample matrix, and lack of statistically representative samples are the challenges in development of sewage-based epidemiology for monitoring the trends in COVID-19 mass infection. The loading of viral genome also depends upon the inhabitants served by sewage treatment plant in order to rank communities with respect to their community-wide infection rates (Daughton 2020). Quantitative detection in wastewater was directly linked to the number of cases reflecting the circulation of COVID-19 in population (Wurtzer et al. 2020). A few studies have shown the median viral concentration ranging between $5 \times 10^{3}$ and $5 \times 10^{7.6}$ copies $/ \mathrm{mL}$ in the faces of positive SARS-CoV-2 cases (Zhang et al. 2020d). It was also observed that the load of virus in faces is little higher $(1.26 \times$ $10^{5}$ copies $\left./ \mathrm{mL}\right)$ in patients experiencing diarrhea in comparison to non-diarrheal patients $\left(7.9 \times 10^{3}\right.$ copies $\left./ \mathrm{mL}\right)$ (Cheung et al. 2020). The SARS-CoV-2 viral load in swage/wastewater was detected in countries reported with low as well as high prevalence of COVID-19 cases. Almost $22 \%$ of the wastewater samples in Australia were detected positive for SARS$\mathrm{CoV}-2$ with the viral concentration 1.9 to 12 copies $/ 100 \mathrm{~mL}$ (Ahmed et al. 2020). Viral concentration in 11 treatment plants and 38 other locations in UAE ranged between 34 and 75 copies $/ 100 \mathrm{~mL}$. Similarly, in India where huge number of COVID-19 positive cases were detected, high viral RNA concentration of $8.05 \times 10^{3}$ copies $/ 100 \mathrm{~mL}$ was recorded in influent samples (Kumar et al. 2020a). Furthermore, 20\% of the samples from secondary-treated effluent showed $2.4 \times 10^{2}$ copies $/ 100 \mathrm{~mL}$ of viral load while the influent samples were tested negative for CoV-2 (Haramoto et al. 2020a, 2020b). Such discrepancies could be due to huge difference in volume of water samples $(20 \mathrm{~mL}$ for influent and $5000 \mathrm{~mL}$ for treated water) (Saawarn and Hait 2021). Different primers and probes targeting different parts of the viral genome could also results into varying results of detection in different water samples. For instance, from different sets of primers $(\mathrm{N} 1, \mathrm{~N} 3$, and $\mathrm{E})$, N1 was found to produce high reproducibility. In contrast, a high frequency of positive amplification was observed when ORF 1 ab was targeted as compared with the $\mathrm{E}, \mathrm{S}$, and $\mathrm{N}$ genes.
Therefore, this could be entirely attributed to sensitivity of primer/probe used, interferences or inhibitors to PCR and stability of the virus and/or viral genome in the wastewater samples from different sites (Amoah et al. 2020). There are different methods that have been opted for calculation of copies or viral load in water sample. Medema et al. 2020b estimated the expected concentration of $\mathrm{CoV}-2$ by undertaking a Monte Carlo simulation assuming no decay of RNA. The concentration was given as (Eq. 1):

$C_{\text {sewage }}=N . f l . C_{\text {faces }} / Q$

where $N$ is the number of shedders, $f l$ is the fecal load (g. person $^{-1}$ day $^{-1}$ ), $C_{\text {faces }}$ is the concentration of RNA in faces of infected people, and $Q$ is the total flow of sewer in a day. In another study, a new index namely normalized viral load (NVL) was calculated using the N1 standard curve equation (Eq. 2) (Yaniv et al. 2020):

Normalized viral load $(N V L)$
$=\frac{\text { RNA copy number }(\# / \mathrm{L}) * \text { Cummulative sampling floe }(\mathrm{L})}{\text { population size } / 1000}$

Viral concentration decreases from $3 \times 10^{3}$ copies $/ 100 \mathrm{~mL}$ to 2 copies $/ \mathrm{mL}$ in wastewater systems due to large dilution and other unknown factors (Wu et al. 2020b). This dilution roughly decreases the viral load approximately by 5 -fold of magnitude or more. Therefore, the sewage samples with low viral load may require pre-concentration of large volumes of sewage. Besides insufficient concentration of genetic material, sewage matrix contains a large number of interfering substances such as enzymatic molecules including ribonuclease (RNases) that can easily degrade the viral RNA. Sample matrix can also contain inhibitors like potassium chloride, sodium chloride, EDTA, and phenol that have huge impact on viral genetic material (Demeke and Jenkins 2010). Therefore, utmost care is needed for sewage sample handling and utilization of other reagents, glassware for conservation of original characteristics of sample in case of SARS-CoV-2.

\section{Sampling strategies}

Relying on sewage-based surveillance also requires a robust sampling strategy to actually estimating true extent of infection. Determination of viable SARS-CoV-2 virus half-life in sewage and establishing a sampling strategy and schedule that will represent the whole population is another big challenge that needs to be resolved (Orive et al. 2020). Data from developed countries possibly make sense of surveillance for drawing the full picture of hotspots as the data is quite robust. However, at the same time, in developing countries like India where treatment facilities are either overloaded or 
underperforming, it is difficult to make some logical interpretations. Selectively checking the sampling points from upstream (as the inlet is a mixture of many areas) reduce the chances of putting a burden on zones by excluding the communities where the novel coronavirus may currently not pose a threat. Therefore, it is crucial to develop a robust sampling strategy to generate representative information for mass investigation of COVID-19 outbreak and other epidemics as well. Only a few studies have provided the time of grab sampling while detecting SARS-CoV-2 in wastewater (Randazzo et al. 2020; Rimoldi et al. 2020). Moreover, recording such information of sampling provide accurate picture of the peak of daily fecal load in sewage/wastewater. As the viral content in the sewage samples depends upon the flow rates, viral concentrations and fluctuation during the day and therefore composite sampling technique could be more helpful and acceptable for drawing the true picture (Simpson 2013; Gerrity et al. 2021; Medema et al. 2020b; Yaniv et al. 2020). Composite sampling can give true average concentration of the viral RNA during the collection period, without discriminating any peak values recorded within the sampling period. Concentration of volume less than $100 \mathrm{~mL}$ of sewage seems to be adequate for enteric viruses, whereas volume of at least $1 \mathrm{~L}$ of sample was suggested to obtain high of concentration of enteric viruses in both treated and untreated sewage (Farkas et al. 2018; Haramoto et al. 2009). However, in the case of SARS-CoV2 , up to $500 \mathrm{~mL}$ sample of raw sewage has been used, whereas a few have used up to $2 \mathrm{~L}$ of the sample also (MichaelKordatou et al. 2020; Nemudryi et al. 2020; Ahmed et al. 2020; Wurtzer et al. 2020). Viability of SARS-CoV was significantly reduced when kept at $56^{\circ} \mathrm{C}$ for $90 \mathrm{~min}$ (Duan et al. 2003). An apparent inactivation was also observed for SARS$\mathrm{CoV}-2$ virus within $5 \mathrm{~min}$ when incubated at $70^{\circ} \mathrm{C}$ (Chin et al. 2020) Therefore, any fluctuations in temperature might affect the true concentration of viral load in water samples. Thus, it is recommended that the collected samples should be kept in any case maintained at low temperature (preferably $4{ }^{\circ} \mathrm{C}$ ) at the collection time and stored in ice box during transportation as this would help for preservation of viral load and viability.

\section{Detection methodologies}

Currently, the confirmation test for humans is based upon the detection of specific sequence of virus RNA by nucleic acid amplification test (NAAT) based on RT-PCR and serological test (antigen/antibody test) as approved by Centers for Disease Control and Prevention (CDC 2020b). RNA extraction of SARS-CoV-2 requires at least biosafety level-II (BSL-II) or the equivalent lab. Antibody testing can also be performed for checking COVID-19 disease but only when there is development of antibodies in response to the infection. However, antibody test is not recommended for currently sick person as there may be chances of no antibodies in someone with a current COVID-19 infection. Due to the shortage of molecular testing facilities and tools, various diagnostic test manufacturers have developed novel rapid test kits. However, validation of these test kits is still not confirmed by WHO. These kits are either based on the detection of viral proteins in samples taken from respiratory tract (sputum, throat swab) or in blood or serum, of antibodies produced in human against infection. A list of already developed test methods along with test methods under development that might prove to be useful for SARS-CoV-2 detection is given in Table 2. However, applicability of these methods for detection of SARS-CoV-2 in sewage is still unknown.

Since the knowledge about half-life of SARS-CoV-2 (viable) in sewage is still limited, the detection methodologies should be more aligned toward both viable and non-viable particles. Hence, detection in the sewage could probably be done using associated debris like RNA fragments, capsid subunits or mRNA, and viable virus which is certainly relatable to the direct shedding from stool and urine.

Moreover, not whole population contributes to the total viral concentration, but specifically depends on the number of positive cases in the community served by a treatment plant. Therefore, viral copy numbers in sewage are significantly diluted in comparison to the viral concentration in the feces and are not consistent. These figures of viral load are important for better implementation of sewage-based epidemiological approach in developing an early warning system and consequent effective intervention system that will require a rapid analytical method for the on-site detection of viruses at the sample collection point.

Nucleic acid amplification test The detection and quantification methodology of coronaviruses (SARS CoV-2, SARS$\mathrm{CoV}$ ) in sewage is the same as of stool or rectal swab and is done by RT-PCR technique (Wang et al. 2005; Ahmed et al. 2020; Holshue et al. 2020; Medema et al. 2020a; Wang et al. 2020c; Wu et al. 2020b; Zhang et al. 2020a).

Before jumping to the detection of any genetic material, the sample needs to be concentrated and extracted effectively. Essays like RT-qPCR for detection of viruses in water matrix essentially requires sample processing using different physicochemical methods such as pre-concentration [by polyethylene glycol (PEG) precipitation], adsorption and elution [using electropositive filter media particle $\left(\mathrm{Al}(\mathrm{OH})_{3}\right.$ plus silica gel, buffer solutions], ultrafiltration, glass wool filtration, ultracentrifugation, etc. (Ahmed et al. 2020; La Rosa et al. 2020). Variety of RNA extraction methods, insufficient nucleic acid amount due to incomplete cell lysis, and presences of RNases that degrade RNA are some of other associated challenges that may be handled during RNA extraction and subsequently SARS-CoV-2 detection in influent wastewater (Mumy and Findlay 2004). In RT-PCR technique, extraction methods are specific and have been validated by CDC. Although both 
Table 2 Possible diagnostics emerged for SARS-CoV-2

\begin{tabular}{|c|c|c|c|}
\hline Tests & Biomarkers & Working principle & Reference \\
\hline $\begin{array}{l}\text { Clustered Regularly Interspaced Short } \\
\text { Palindromic Repeats (CRISPR) }\end{array}$ & Nucleic acid & $\begin{array}{l}\text { PCR, CRISPR/Ca9-mediated lateral flow nucleic } \\
\text { assay (CASLFA) }\end{array}$ & Wang et al. 2020b \\
\hline CRISPR & & $\begin{array}{l}\text { RPA, CRISPR- Cas13- or Cas12-mediated } \\
\text { detection via fluorescent and colorimetric readouts }\end{array}$ & Kellner et al. 2019 \\
\hline $\begin{array}{l}\text { Loop-mediated isothermal } \\
\text { amplification (LAMP) }\end{array}$ & & $\begin{array}{l}\text { isothermal DNA synthesis using self-recurring } \\
\text { strand displacement reactions; sample gets } \\
\text { turbid on positive test }\end{array}$ & Imai et al. 2007 \\
\hline $\begin{array}{l}\text { Recombinase polymerase } \\
\text { amplification (RPA) }\end{array}$ & & $\begin{array}{l}\text { forward and reverse primers bind to DNA and } \\
\text { amplification occurs at } 37^{\circ} \mathrm{C}\end{array}$ & Amer et al. 2013 \\
\hline Feluda test (Paper Based Approach) & & $\begin{array}{l}\text { Based on cutting-edge gene-editing } \\
\text { CRISPR-CAS-9 technology }\end{array}$ & Azhar et al. 2020 \\
\hline CDC SARS-CoV-2 qRT-PCR & & transcription-based amplification for RNA targets & CDC 2020b \\
\hline $\begin{array}{l}\text { Nucleic acid sequence-based } \\
\text { amplification (NASBA) }\end{array}$ & & RNA targets amplification (transcription) & Wat et al. 2008 \\
\hline Rolling circle amplification RCA & & $\begin{array}{l}\text { DNA polymerase extend the circular primer and } \\
\text { replicate the sequence repeatedly }\end{array}$ & Martel et al. 2013 \\
\hline Abbott ID NOW COVID-19 & & PCR isothermal test amplifying virus genome & Abbott 2020 \\
\hline RT-LAMP & & reverse transcriptase LAMP reaction for RNA targets & Shirato et al. 2007 \\
\hline SARS-CoV-2 DETECTR assay & & lateral flow assay: CRISPR-Cas12-based & Broughton et al. 2019 \\
\hline Quantum dot barcode & & $\begin{array}{l}\text { RPA detection of captured viral DNA via } \\
\text { multiplexed quantum beads }\end{array}$ & Kim et al. 2016 \\
\hline Magnetic bead & & $\begin{array}{l}\text { Bacteria isolated by magnetic beads for PCR } \\
\text { detection }\end{array}$ & Nilsson et al. 1996 \\
\hline Smartphone dongle & Protein & cassette operating an ELISA (microfluidics-based) & Laksanasopin et al. 2015 \\
\hline Paramagnetic bead & & magnetic separation of protein targets & Aytur et al. 2006 \\
\hline ELISA & & $\begin{array}{l}\text { enzymatic reaction producing colored product } \\
\text { when target is present }\end{array}$ & Rowe et al. 1999 \\
\hline Simoa & & $\begin{array}{l}\text { digital readout of colored product by enzymatic } \\
\text { reaction when target present }\end{array}$ & Rissin et al. 2010 \\
\hline Biobarcode assay & & $\begin{array}{l}\text { protein signal is indirectly linked and detected } \\
\text { by amplifying DNA conjugated to gold } \\
\text { nanoparticle }\end{array}$ & Thaxton et al. 2009 \\
\hline Rapid antigen test & & $\begin{array}{l}\text { gold-coated antibodies give colorimetric test in } \\
\text { the presence of target }\end{array}$ & Bosch et al. 2017 \\
\hline Magnetic bead isolation & Whole bacteria & magnetic isolation of bacteria & Bicart-See et al. 2016 \\
\hline
\end{tabular}

CDC-validated and other relevant extraction kits are in use, till now there are no comparative studies on different RNA extraction methods that would help in establishing their RNA extraction efficacies from sewage samples. To be specific, there is no other standardization of RNA extraction protocol available that allow comparable SARS-CoV-2 extraction from sewage samples (Michael-Kordatou et al. 2020).

Although PCR is a sensitive and specific technique, requirements for complicated sample handling, skilled staff, and a long duration of data analysis (4-6 h) and processing are not favorable in real-time monitoring of samples on location.

Paper-based device Very recently, potential of paper-based devices that can be used for on-site detection of SARS-CoV2 in sewage is also highlighted. These devices are small, portable, and can help in tracking virus carriers in the community (Mao et al. 2020b).
Loop-mediated isothermal amplification Loop-mediated isothermal amplification (LAMP) is another nucleic acid amplification technique that has been used for detection of SARSCoV-2 RNA from different body fluids and also expected to be developed for easy and rapid detection of the viral RNA in wastewater media, especially in situations where sufficient analytical services are not available (Giri and Rana 2020).

Others Similar to the detection in humans, at present RT-PCR and its allied approaches, ELISA in association with most probable number (MPN) methods are also used for quantifying the viable and non-viable virus particles in sewage systems (Daughton 2020).

Development of such low-cost device would definitely serve as an early monitoring tool even in case of asymptomatic carriers in new areas, especially in developing countries that lack extensive testing facilities. However, their low accuracy, specificity, and sensitivity against 'gold standard' 
protocol (RT- PCR) is still a big challenge. Therefore, looking at the exponentially incremental trend of occurrence of COVID-19 globally, there is an urgent need for development of rapid and simple detection method for sewage sample. Achieving high sensitivity (especially considering low viral concentration), specificity and selectivity toward viable or non-viable viral entities in a complex sample matrix are the essential factors for assays to produce comparable results with clinical studies. Hence, development of suitable detection methodologies for detection of novel coronavirus and associated particles will dictate the future of sewage surveillance.

\section{Available treatment option and chances of occurrence of viruses in treated water}

The prolonged occurrence of SARS-CoV-2 viral RNA in fecal samples can allow its existence at various stages of treatment facility. Removal or treatment of such threatening fragments would be one of the biggest challenges for treatment facilities. Hydrophobicity (given by the presence of protein envelop) pertained by viruses can make them less soluble in sewage water. However, this can enhance their adherence to the solids or organic matter present in sewage and provides more protection from predatory microorganisms. It suggests that an early removal can also be expected if the solids settled out. Furthermore, it has been observed that the survival of the viruses in primary treatment system is slightly higher than the secondary due to the presence of higher suspended solids that offer protection from inactivation (Gundy et al. 2009). Viruses if concentrated in suspended solids can be removed by membrane bioreactors (MBRs) as an efficient filtration technique. Appropriate reduction over 4 logs of pathogenic viruses has been observed with full-scale MBR in wastewater treatment (Chaudhry et al. 2015). However, removal capability of SARS-CoV-2 with these traditional bioreactor systems is still unclear due to lack of research and absence of experimental data (Oliver et al. 2020). Specific disinfection approaches such as simple chlorination for disinfecting coronaviruses is still considered to be easiest and economical method. But then again, even after the process of chlorination, occurrence of low level of adenovirus, norovirus, and human enteric viruses have been observed with seasonal changes (Purnell et al. 2016; Jumat et al. 2017). Survival of adenovirus after the exposure to UV light has also been observed. This may happen due to the irregularity in the action of polychromatic medium and low-pressure lamps (Qiu et al. 2015). Therefore, disinfection through chlorination and UV exposure again questioned the efficiency of treatment facilities. Recently, it was demonstrated that ca. 2 Log removal could be achieved after primary and secondary treatment and $>100$ copies $/ \mathrm{mL}$ was detected in the treated water. Disinfection using chlorination resulted in the complete removal of SARS-CoV-RNA.
Viral RNA was detected only once due to inadequate chlorine dose (Ali et al. 2020). Since it is believed that coronavirus being enveloped viruses are more susceptible toward oxidants than non-enveloped, their low removal after traditional oxidants is of huge concern (La Rosa et al. 2020).

The major focus of the current research is inclined toward the detection of SARS-CoV-2 mainly in inlet of sewage treatment plants and only a few have provided the data for occurrence of the virus at different stages of treatment plants. Inadequate treatment and uncontrolled discharge of sewage could allow virus to enter into environment. More recently, SARS-CoV-2 RNA was also detected in surface water body (Quito's river, Ecuador) at concentration of $10^{5}-10^{6}$ gene copies/L in where disposal of untreated sewage is practiced (Guerrero-Latorre et al. 2020). Positive signals for occurrence SARS-CoV-2 were also obtained in river samples probably due to combined sewage overflows (Rimoldi et al. 2020). On the contrary, river samples from Yamanashi Prefecture Japan showed absence of SARS-CoV-2 (Haramoto et al. 2020a). However, negative reports do not necessarily indicate the absence of virus in the sample as detection and other methodologies consideration still lack adequate quality control measures and require trained personnel that may again complicate the viral determination in wastewater (Michael-Kordatou et al. 2020). It is also noteworthy, incidence of respiratory disease was linked to the swimming in sewage-contaminated water, and similar situation can also exacerbate in case of current SARS-CoV-2 (Kitajima et al. 2020). Reusing the water for agricultural practices from downstream of water bodies receiving untreated sewage and associated potential exposure of SARS-CoV-2 has also not been elucidated.

A comprehensive review shed light upon the efficacy of the disinfection using chlorination and UV irradiation in water/ wastewater and suggested that doses suggested for nonenveloped viruses are expected to efficient for inactivation for the coronaviruses (Silverman and Boehm 2020). In a study, it was observed that the viral SARS-CoV-2 RNA could be detected in all stages of treatment facility. Approximately 2 log removal was achieved at primary and secondary treatment setting indicating high attachment of viral RNA to large biosolids (Ali et al. 2020). However, the viral RNA could still be detected in the effluent from secondary treatment system. This warns the chance environmental transmission especially in developing countries due to inadequate performance of existing treatment facility, absence of tertiary treatment system, and disposal of untreated sewage/wastewater in surface water bodies or on to land. Therefore, development and reinforcement of treatment facilities to prevent such chances of transmission is an absolute necessity. However, according to the new control and prevention guidelines issued by the U.S. Occupational Safety and Health Administration (OSHA), it dictates that the disinfection practices like oxidation with hypochlorite (i.e., chlorine bleach) and peracetic acid, as well as 
inactivation through the use of ultraviolet irradiation are considered to be sufficient for SARS-CoV-2 (OSHA 2020).

\section{Indiscriminate use of therapeutic and non-therapeutic antimicrobials: environmental presence of CECs and antimicrobial resistance}

Therapeutics In the absence of any particular established drugs against Covid-19, many antivirals and antibiotics are being used for controlling the disease (Kumar et al. 2020b; Rawson et al. 2020). Although continuous contribution of pharmacies for tackling and easing the burden of current COVID-19 on already burdened healthcare system in much needed, unconfirmed and often misleading drug information for preventing or treating COVID-19 and panic behavior of people around the world has caused a surge in unsafe medication habits (Kretchy et al. 2020). Moreover, people are selfmedicating therapeutic agents (antibiotic and antiviral) in an unwise attempt to protect themselves from infection. It will not be an exaggerated apprehension that a huge demand and an increase in use of various therapeutics including antibiotics and antivirals will lead to an increase in the occurrence of their residuals in untreated sewage. The situation is worse in developing countries having unregulated over-the-counter sales of medicines and a weak sewage treatment infrastructure. Influents containing antivirals can significantly disrupt the microbial consortia and destabilize the overall functioning of treatment facility from where they may enter the natural systems (Slater et al. 2011). Similar circumstances during current COVID-19 disease may lead to the development of new antimicrobial resistant (AMR) and increase in the concentration of contaminants of emerging concern (CEC) in wastewater (Usman et al. 2020a) including antibiotic resistant bacteria (ARBs) and antibiotic resistant genes (ARGs). It is well recognized that AMR is a global threat toward the human and environmental health (Maillard et al. 2020). Considering the easy and rapid mutation in virus genome, the emergence of resistance to the antiviral and antibacterial drugs is highly susceptible and could generate challenges for treatment of humans in the post COVID-19-pandemic Anthropocene (Kumar et al. 2020c). Furthermore, there are no data available whether the microbial consortia in treatment system can degrade the pharmaceuticals when exposed to pandemic-scale doses. The future research and innovation projects related to Covid-19 should support integrated and cross-sector approaches for risk-management and combine the research areas of CECs, pathogens and AMR.

Non-therapeutic antimicrobials Contact with contaminated surface is one of the major routes of disease transmission. Therefore, WHO-WASH (water, sanitation, and hygiene) has recommended frequent cleaning/washing hands for at least $20 \mathrm{~s}$ as one of the most important steps to avoid the spread of COVID-19 (White et al. 2020). Unfortunately, due to continuous news of spread of COVID-19 and struggle for adequate social and medical support due to restricted normal activities in many parts of the world, people are in great fear that has left many in high stress levels (Huang and Zhao 2020; Kretchy et al. 2020). Commonly available soaps are effective enough for inactivation of enveloped viruses and therefore, soaps with additional antibacterial agents may not always be required for inactivation of SARS-CoV-2 (UNESCO 2020). Despite this, usage of disinfectants and soaps with active antibacterial ingredients have been amplified as evident from their sharp increase in sales worldwide (Cleaning Matters Coronavirus 2020). Quick transmissions from uncertain fomites have created a havoc of panic buying of sanitizers (alcohol/non-alcohol based), floor cleaners, soaps handwashes, detergents, and other personal protective equipment. Overuse of these disinfecting agents has critically posed a threat of occurrence of their excessive residuals in wastewater. In particular, handwash and soap contains triclocarban and triclosan which are indiscriminate killer of bacteria and other microbial communities (Pycke et al. 2014). Triclosan being an antibacterial agent can easily disfunction the biological (aerobic/anaerobic) treatment systems. In the present scenario, increased use of handwash, sanitizer's load-up triclosan down the drain and eventually paved its way to the sewage treatment plant that can severely interfere with the plant's bacterial diversity (Lozano et al. 2013). Triclosan and Triclocarban are harmful to mammals and can also be metabolized by plants (Olaniyan et al. 2016). These metabolites may act as metabolic precursors (including chlorinated dibenzo-p-dioxins and chlorinated anilines) of carcinogens (Paull and Halden 2005; Macherius et al. 2012). Hence, for all practical purposed safeguarding the entire water cycle: from water resources of river basins, estuaries, and oceans to wastewater discharge, recycle and reuse will be highly challenging in post-COVID-19 pandemic world.

\section{Sewage surveillance of populous developing countries: current Indian scenario}

The robust sewage treatment and tracking in developed countries can make full use of sewage surveillance data to help in predicting any community infection and identification of possible hotspots. On the contrary, the growing crisis due to COVID-19 has disproportionately hit developing countries. Minimum-resourced healthcare units and fragile health system may exacerbate the current infection status as nearly $75 \%$ of the population in developing countries lack basic need of water and sanitation (UNDP 2020). Poor urban planning system and overpopulated cities and traffic congestion further 
weakens the efficiency of sewage water treatment facilities that may again add to the caseload.

As per the World Water Development Report-2017 (WWDR-United Nations), over $80 \%$ of wastewater worldwide and more than $95 \%$ in developing countries is directly disposed in to environment without any treatment (WWDR 2017). It is also very common that downstream of rivers, canals, etc. (surface water bodies) are being used for purposes like drinking water or irrigation. In such vulnerable conditions, exposure to SARS$\mathrm{CoV}-2$ virus is a possible threat to the communities. Therefore, any unintentional contamination of surface water bodies with untreated sewage which is commonplace in developing countries can lead to mass infection (Usman et al. 2020b).

\section{Challenges for sewage-surveillance in developing countries}

The importance of access to clean water and basic sanitation for good public health has been again highlighted by COVID19 pandemic. Well-structured water, sanitation, and hygiene are crucial for the safety of human health during disease outbreaks (WASH 2020). In lack of these basic needs, developing countries are at risk of direct exposure to viruses, bacteria, and parasites and hence are at risk to waterborne diseases. Inadequate treatment facilities, exposure to sewage, and fecal sludge can be potential reason of spreading of COVID-19 in developing countries. At the moment, high prevalence of COVID-19 in resourceful countries can be linked to availability of screening and testing facilities whereas low prevalence in poorly resourced regions may be linked to underreporting (Kavanagh et al. 2020; Hart and Halden 2020). Looking at the developing countries, such as Africa, hosting $62 \%$ of urban population are under potential threat of getting infected and could become hotspot of COVID-19. Other countries such as Bangladesh, Afghanistan, Nepal, India, Myanmar, and Indonesia where $\sim 22-63 \%$ of the urban population is living in slums could spread COVID-19 due to poor sanitation (Pandey et al. 2021). Therefore, sewage-surveillance may provide critical information for COVID-19 spread in many lowincome countries where healthcare system, screening, and testing and access to basic hygiene are poor. However, there are many challenges for sewage-surveillance in developing countries that have been listed below:

I. Inadequate sewage treatment facilities: The number of treatment facilities serving the population is very less and only a few percent (8-28) of sewage/wastewater undergoes treatment procedure (UNU-INWEH 2019).

The surveillance begins with sampling of influent of treatment plants, which are not representative in developing countries due to lack of proper sewer system leading to insignificant collection of sewage, low number of treatment plants, etc. This kind of surveillance does not produce a reliable data and it becomes impossible to estimate the prevalence of viral content circulating in whole population. Sampling and monitoring plan for such nations should represent the local reality to generate true data for early warnings for possible disease prevalence.

II. Low service level of operational facilities: It has been also reported that the treatment facilities are not working up to their service level. However, it is also mentioned that 80 95\% treatment facilities are not even in working condition (WaterAid 2019).

III. Dysfunctional operational facilities: Existing facilities that are in operational condition does not work adequately due to their possible inappropriate technology choices, poor design and inadequate operations and maintenance (O\&M) (WaterAid 2019).

IV. Mismanagement of sewage: Inadequate separation of runoff from domestic effluents leads to combined sewer overflows that can further increase the chances of pathogenic exposure (WWRD 2017).

V. Unavailability of analytical services: Testing of SARS$\mathrm{CoV}-2$ in sewage requires expensive equipment and skilled laboratory staff for processing and handling the sewage sample. However, most of the treatment facilities are not equipped with laboratory even to monitor the regular physicochemical changes.

VI. Open-defecation: Open-defecation is prevalent in lowincome and densely populated countries and considered to be worst kind of sanitation. The practice significantly increases implications to public health and add huge bacteriological and virus population other than the species of interest. Therefore, it increases the complexity of sample matrix hindering the detection of SARS-CoV-2.

In the absence of an adequate sanitation facility, transmission of COVID-19 through fecal-oral route are of huge concerns especially in countries like India that have high open defecation rate. After major improvements in sanitation and hygiene education since 2012, the picture of completely OD free India is still not clear. Almost $28.7 \%$ of rural population of the whole country lacks access to latrines (National Statistical Office 2019). Recent study has indicated that $44 \%$ of the population in rural areas (of Bihar, Madhya Pradesh, Rajasthan, and Uttar Pradesh) defecate in open and those with private toilets (23\%) prefer to defecate outside (RICE 2019). Moreover, during the pandemic, setting up of new quarantine centers, healthcare facilities, dedicated testing laboratories, etc. topped up with the seemingly unhygienic sanitation practices by the millions of Indian migrant workers fleeing to their villages have obviously added to the viral load in sewage/ wastewater (Kataki et al. 2020). Such ground realities cannot be overlooked and should be accounted for possible transmission of SARS-CoV-2 through unregulated wastewater management systems. 
Future actions should concentrate not only on setting up adequate treatment facilities but also on public education and community-led actions to eliminate open defecation activities, while better designs and prevention strategies to minimize the transmission of fecal contaminants associated with the usage of squat toilets. Fecal transmission of human diseases remains a continuing challenge to public health, and having access to better sanitation services should be included as a priority in their long-term community development strategy (Sun and Han 2020). On-site sanitation (OSS) systems are the most effective means of treating excreta in low-income countries as these facilities aim at treating human waste at source and can provide a hygienic and affordable method of waste disposal. (Rose et al. 2015).

However, developing countries like India where sewage/ wastewater treatment plants are either overloaded or underperforming, it is difficult to make any logical interpretations. Sewage generation, existing treatment capacity, and service level in India are summarized in Table 3. An estimated 61,754 million liters of household wastewater per day (MLD) is produced from urban centers (ENVIS 2019). The present installed capacity of existing sewage treatment facilities is 22,963 MLD, i.e., only around $37 \%$ of the total sewage generated per day (ENVIS 2019). Owing to service and maintenance issues, even the current treatment capacity is often not adequately utilized $(81.1 \%)$. The operation and maintenance of existing plants is unsatisfactory, as almost $39 \%$ of treatment plants do not comply with the minimum requirements specified in the Environmental (Protection) Rules for discharge into streams (CPCB 2015).

The current treatment capacity remains underused in a number of towns while a lot of waste is dumped in the same town without treatment. Thus, the gap between existing facilities, service level, and required demand are staggeringly high. Facilities should be developed to bridge this gap to achieve effective management of wastewater in the surface waterbodies' catchment. Government of India assists local authorities in setting up water treatment plants under the Ganga Action Plan and subsequently the National River Conservation Plan (National River Conservation Plan (NRCP) 2020). Whether these are really able to secure the urban water system is the question that needs to be answered. Since the challenge is huge and equally important, it may take a longer time to tackle whole wastewater treatment. Currently, 920 sewage treatment plants installed in India works on various treatment technologies such as activated sludge process (ASP), up-flow anaerobic sludge blanket (UASB), oxidation pond, etc. Advanced technologies such as MBR and sequential batch reactor (SBR), are being adopted for sewage treatment. Disinfection by chlorination of drinking and sewage water is practiced only in a few plants.

The water quality criteria in India in terms of total coliforms for receiving waterbodies varies between 500 and $5000 \mathrm{MPN} / 100 \mathrm{~mL}$ based on the designated best uses, and are thus quite relaxed (CPCB 2020). In addition to it, discharge of untreated sewage into open storm water drains polluting the waterbodies that contributes approximately $60 \%$ of urban India's waste and rendering it unfit for human use. Therefore, risk of transmission through water does exist. Though considering the subsequent dilution it may not be significant, but it is difficult to analyze the extent. Thus, in view of current SARS-CoV-2 spread, mere compliance with discharge norms is not enough. Implementation of stringent water quality standard is required to prevent unwarranted spread of infectious diseases at large scale.

\section{Future needs and way forward}

Whether sewage/wastewater can lead to fecal-oral contamination that can further spread the COVID-19, is still unknown. While feces/stools have been shown to contain the viable SARS-CoV-2, the extent of its potential threat to humans needs to be adequately assessed. Despite many challenges like low concentration of viral entities in samples and complex sample matrix, sewage-based surveillance is an emerging approach for early prediction of waves of infection. This approach may be effectively used in developing countries where human diagnosis that would cost billions of dollars using conventional techniques is difficult to conduct at large scale. Such routine analysis of sewage surveillance could only be used as a non-invasive early-warning system to alert communities to COVID-19 infections. The chances of infection will increase if social distancing measures are not followed especially when the lockdown will be lifted. However, there are huge challenges for sewage-based epidemiology in nations with lowor/and middle-income countries due to inadequate treatment/ non-functional/dysfunctional facilities. Poor analytical services, unskilled professionals, and lack of access to clean water and sanitation are add-on to the current worse situation.

Table 3 Sewage generation, treatment capacity, and service level in India (ENVIS 2019*; CPCB 2020\$)

\begin{tabular}{llllll}
\hline $\begin{array}{l}\text { Sewage Generation* } \\
(\times 1000 \mathrm{MLD})\end{array}$ & $\begin{array}{l}\text { Available treatment } \\
\text { capacity* }(\times 1000 \mathrm{MLD}) \\
{[\% \text { of total generation] }}\end{array}$ & $\begin{array}{l}\text { Service level* }(\times 1000 \\
\text { MLD) }[\% \text { of available } \\
\text { capacity] }\end{array}$ & $\begin{array}{l}\text { Service Level* }(\times 1000 \\
\text { MLD) [\% of total } \\
\text { generation] }\end{array}$ & $\begin{array}{l}\text { Plants } \\
\text { not complying } \\
\text { with standards }(\%)\end{array}$ & $\begin{array}{l}\text { Surface water } \\
\text { criteria } \$ \text {-total coliforms } \\
(\mathrm{MPN} / 100 \mathrm{~mL})\end{array}$ \\
\hline 62 & $19[81.1]$ & $19[30]$ & 39 & $500-5000$ \\
\hline
\end{tabular}


Currently, nucleic acid amplification test (NAAT)-based RTqPCR assay is being used for SARS-CoV-2 RNA detection in sewage samples. Alternative rapid test methods or assays must be validated against NAAT-based results to increase the fidelity of the acquired analytical data. Development of a robust, rapid, and easy to use analytical technique is highly desirable. At the same time, sewage/wastewater treatment plants are critical nodes to stop the influx of virus transmission and important for protecting the public health. Therefore, current research should also be focused on development of treatment facilities to prevent further transmission of coronaviruses from wastewater of quarantine centers, healthcare setups, community clinics, and nursing homes. This would not only improve the availability of clean water to the public sector but also reduce the chances of secondary transmission of pathogenic microorganisms. A better understanding of transmission of viruses like SARS-CoV-2 and other coronaviruses is needed with additional stringent regulatory guidelines of higher-log removal capacity to ensure the safe potable water. Impact of excessive use of therapeutics and nontherapeutics (disinfectants) at pandemic-dose toward the efficacy of sewage treatment systems especially the biological components which may increase the chance of AMR need to be assessed. Interconnectedness of wastewater plumbing network can facilitate the spread of SARS-CoV-2 within human settings (Gormley et al. 2020). Hence, a proper check-up of plumbing system is highly recommended.

To address the present and future challenges, the government and scientific community including water engineers, environmentalists, microbiologist, and chemists have to come together and should work in a synergistic way to protect the citizens of their own and other countries. Concerns have been expressed on the productivity of national lockdown and the serious damage that it can cause to a country's economy. It is imperative that lockdowns alone are not enough to fight against COVID-19; rather, other measures must be taken to fight against further waves of infections (UN News 2020).

Acknowledgement Director, CSIR-NEERI is thankfully acknowledged for giving the opportunity to pursue the research in CSIR-NEERI, Nagpur, India. DP is grateful to the University Grants Commission, India for providing a Senior Research Fellowship. The article is checked for plagiarism using the iThenticate software and recorded in the Knowledge Resource Center, CSIR-NEERI, Nagpur for anti-plagiarism (KRC No.: CSIR-NEERI/KRC/2021/JAN/WWTD/3).

Author contribution Contributions of all authors to this work were as follows:

Deepak Panchal: Conceptualization, writing — original draft and editing

Om Prakash: Conceptualization, writing - original draft

Prakash Bobde: Literature reviewing

Sukdeb Pal: Designed study, conceptualization, writing, reviewing editing and supervision

Funding DP is supported by Senior Research Fellowship from the University Grants Commission, India. No external funding has been received for the current study.
Data availability The datasets used and analyzed during this article are available from the corresponding author on reasonable request

\section{Declarations}

Ethics approval and consent to participate Not applicable.

Consent for publication Not applicable.

Competing interests The authors declare that they have no competing interests.

\section{References}

Abbott (2020) https://www.abbott.com/IDNOW.html?CID=OUS_OK. (Accessed on November 2, 2020)

Ahmed W, Angel N, Edson J, Bibby K, Bivins A, O’Brien JW, Choi PM, Kitajima M, Simpson SL, Li J, Tscharke B, Verhagen R, Smith WJM, Zaugg J, Dierens L, Hugenholtz P, Thomas KV, Mueller JF (2020) First confirmed detection of SARS-CoV-2 in untreated wastewater in Australia: a proof of concept for the wastewater surveillance of COVID-19 in the community. Sci Total Environ 728: 138764. https://doi.org/10.1016/j.scitotenv.2020.138764

Ali HA, Yaniv K, Bar-Zeev E, et al (2020) Tracking SARS-CoV-2 RNA through the wastewater treatment process. medRxiv. https://oi.org/ 10.1101/2020.10.14.20212837

Al-Tawfiq JA (2020) Asymptomatic coronavirus infection: MERS-CoV and SARS-CoV-2 (COVID-19). Travel Med Infect Dis 35:101608. https://doi.org/10.1016/j.tmaid.2020.101608

Al-Tawfiq JA, Zumla A, Memish ZA (2014) Travel implications of emerging coronaviruses: SARS and MERS-CoV. Travel Med Infect Dis 12(5):422-428. https://doi.org/10.1016/j.tmaid.2014.06. 007

Amer HM, Abd El Wahed A, Shalaby MA, Almajhdi FN, Hufert FT, Weidmann M (2013) A new approach for diagnosis of bovine coronavirus using a reverse transcription recombinase polymerase amplification assay. J Virol Methods 193:337-340. https://doi.org/10. 1016/j.jviromet.2013.06.027

Amirian ES (2020) Potential fecal transmission of SARS-CoV-2: current evidence and implications for public health. Int J Infect Dis. https:// doi.org/10.1016/j.ijid.2020.04.057

Amoah ID, Kumari S, Bux F (2020) Coronaviruses in wastewater processes: source, fate and potential risks. Environ Int 143:105962. https://doi.org/10.1016/j.envint.2020.105962

Aquino de Carvalho N, Stachler EN, Cimabue N, Bibby K (2017) Evaluation of Phi6 persistence and suitability as an enveloped virus surrogate. Environ Sci Technol 51(15):8692-8700. https://doi.org/ 10.1021/acs.est. $7 b 01296$

Arbely E, Granot Z, Kass I, Orly J, Arkin IT (2006) A trimerizing GxxxG motif is uniquely inserted in the severe acute respiratory syndrome (SARS) coronavirus spike protein transmembrane domain. Biochemistry 45(38):11349-11356. https://doi.org/10.1021/ bi060953v

Arora S, Nag A, Sethi J et al (2020) Sewage surveillance for the presence of SARS-CoV-2 genome as a useful wastewater based epidemiology (WBE) tracking tool in India. Water Sci Technol 82:2823-2836. https://doi.org/10.2166/wst.2020.540

Aytur T, Foley J, Anwar M, Boser B, Harris E, Beatty PR (2006) A novel magnetic bead bioassay platform using a microchip-based sensor for infectious disease diagnosis. J Immunol Methods 314:21-29. https://doi.org/10.1016/j.jim.2006.05.006 
Azhar M, Phutela R, Ansari AH, Sinha D, Sharma N, Kumar M, Aich M, Sharma S, Singhal K, Lad H, Patra PK, Makharia G, Chandak GR, Chakraborty D, Maiti S (2020) Rapid, field-deployable nucleobase detection and identification using FnCas9. bioRxiv 2020.04.07.028167. https://doi.org/10.1101/2020.04.07.028167

Bai Y, Yao L, Wei T, Tian F, Jin DY, Chen L, Wang M (2020) Presumed asymptomatic carrier transmission of COVID-19. Jama 323(14): 1406-1407. https://doi.org/10.1001/jama.2020.2565

Bar-or I, Yaniv K, Shagan M, et al (2020) Regressing SARS-CoV-2 sewage measurements onto COVID-19 burden in the population: a proof-of-concept for quantitative environmental surveillance. medRxiv 1-11. https://doi.org/10.1101/2020.04.26.20073569

Bicart-See A, Rottman M, Cartwright M, Seiler B, Gamini N, Rodas M, Penary M, Giordano G, Oswald E, Super M, Ingber DE (2016) Rapid isolation of Staphylococcus aureus pathogens from infected clinical samples using magnetic beads coated with Fc-mannose binding lectin. PLoS One 11:1-12. https://doi.org/10.1371/journal. pone. 0156287

Bogler A, Packman A, Furman A et al (2020) Rethinking wastewater risks and monitoring in light of the COVID-19 pandemic. Nat Sustain 3:981-990. https://doi.org/10.1038/s41893-020-00605-2

Börjesson S, Melin S, Matussek A, Lindgren PE (2009) A seasonal study of the mecA gene and Staphylococcus aureus including methicillinresistant $\mathrm{S}$. aureus in a municipal wastewater treatment plant. Water Res 43:925-932. https://doi.org/10.1016/j.watres.2008.11.036

Bosch I, Puig H, De Hiley M, Carré-Camps M, Perdomo-Celis F, Narváez CF, Salgado DM, Senthoor D, Grady MO, Phillips E, Durbin A, Fandos D, Miyazaki H, Yen CW, Gélvez-Ramírez M, Warke RV, Ribeiro LS, Teixeira MM, Almeida RP, Muñóz-Medina JE, Ludert JE, Nogueira ML, Colombo TE, Terzian ACB, Bozza PT, Calheiros AS, Vieira YR, Barbosa-Lima G, Vizzoni A, Cerbino-Neto J, Bozza FA, Souza TML, Trugilho MRO, De Filippis AMB, De Sequeira PC, Marques ETA, Magalhaes T, Díaz FJ, Restrepo BN, Marín K, Mattar S, Olson D, Asturias EJ, Lucera M, Singla M, Medigeshi GR, De Bosch N, Tam J, GómezMárquez J, Clavet C, Villar L, Hamad-Schifferli K, Gehrke L (2017) Rapid antigen tests for dengue virus serotypes and zika virus in patient serum. Sci Transl Med 9:1-13. https://doi.org/10.1126/ scitranslmed.aan 1589

Broughton JP, Deng X, Yu G, Fasching CL, Servellita V, Singh J, Miao X, Streithorst JA, Granados A, Sotomayor-gonzalez A, Zorn K, Gopez A, Hsu E, Gu W, Miller S, Pan C, Guevara H, Wadford DA, Chen JS, Chiu CY (2019) CRISPR - Cas12-based detection of SARS-CoV-2. Nat Biotechnol

Casanova L, Rutala WA, Weber DJ, Sobsey MD (2009) Survival of surrogate coronaviruses in water. Water Res 43(7):1893-1898. https://doi.org/10.1016/j.watres.2009.02.002

CDC (2020a) Symptoms of coronavirus. https://www.cdc.gov/ coronavirus/2019-ncov/symptoms-testing/symptoms.html?CDC AA_refVal=https $\% 3 \mathrm{~A} \% 2 \mathrm{~F} \% 2 \mathrm{Fwww}$.cdc.gov\%2Fcoronavirus $\overline{\%}$ 2F2019-ncov\%2Fabout\%2Fsymptoms.html. Accessed 20 May 2020

CDC (2020b) Real-time RT-PCR diagnostic panel for emergency use only. Centers Dis Control Prev Div. (https://www.fda.gov/media/ 134922/download)

Chan JFW, Yuan S, Kok KH, To KKW, Chu H, Yang J, Xing F, Liu J, Yip CCY, Poon RWS, Tsoi HW, Lo SKF, Chan KH, Poon VKM, Chan WM, Ip JD, Cai JP, Cheng VCC, Chen H, Hui CKM, Yuen KYA (2020) Familial cluster of pneumonia associated with the 2019 novel coronavirus indicating person-to-person transmission: a study of a family cluster. Lancet 395(10223):514-523. https://doi.org/10. 1016/S0140-6736(20)30154-9

Chaudhry RM, Nelson KL, Drewes JE (2015) Mechanisms of pathogenic virus removal in a full-scale membrane bioreactor. Environ Sci Technol 49(5):2815-2822. https://doi.org/10.1021/es505332n
Chen, Y, Chen L, Deng Q, Zhang G, Wu K, Ni L, Yang Y, Liu B, Wang W, Wei C, Yang, J, (2020a) The presence of SARS-CoV-2 RNA in the feces of COVID-19 patients. J Med Virol

Chen Y, Guo Y, Pan Y, Zhao ZJ (2020b) Structure analysis of the receptor binding of 2019-nCoV. Biochem Biophys Res Commun 525(1): 135-140. https://doi.org/10.1016/j.bbrc.2020.02.071

Chen N, Zhou M, Dong X, Qu J, Gong F, Han Y, Qiu Y, Wang J, Liu Y, Wei Y, Xia J, Yu T, Zhang X, Zhang L (2020c) Epidemiological and clinical characteristics of 99 cases of 2019 novel coronavirus pneumonia in Wuhan, China: a descriptive study. Lancet 395(10223):507-513. https://doi.org/10.1016/S0140-6736(20) 30211-7

Cheung KS, Hung IFN, Chan PPY et al (2020) Gastrointestinal manifestations of SARS-CoV-2 infection and virus load in fecal samples from a Hong Kong cohort: systematic review and meta-analysis. Gastroenterology 159:81-95. https://doi.org/10.1053/j.gastro.2020. 03.065

Chin A, Chu J, Perera M, Hui K, Yen HL, Chan M, Peiris M, Poon L (2020) Stability of SARS-CoV-2 in different environmental conditions. Lancet Microbe 1:e10. https://doi.org/10.1016/S26665247(20)30003-3

Cleaning Matters Coronavirus (2020) supplies run low of anti-bacterial hand-soaps https://www.cleaning-matters.co.uk/Coronavirus-antibacterial-soaps. Accessed 06 August 2020

Coutu S, Wyrsch V, Wynn HK, Rossi L, Barry DA (2013) Temporal dynamics of antibiotics in wastewater treatment plant influent. Sci Total Environ 458-460:20-26. https://doi.org/10.1016/j.scitotenv. 2013.04.017

COVID-19 (2020a) Looming crisis in developing countries threatens to 1284 devastate economies and ramp up inequality, News centre (UNDP). 1285. https://www.undp.org/content/undp/en/home/ news-centre/news/12862020/COVID19_Crisis_in_developing countries_threatens_1287devastate_economies/. Accessed 01 Nov 2020

COVID-19 (2020b) Lockdown across India, in line with WHO guidance, UN News. 24 March 2020. https://news.un.org/en/story/2020/03/ 1060132

CPCB (2015) I. CONTROL OF URBAN POLLUTION SERIES: CUPS / / 2015 INVENTORIZATION OF SEWAGE TREATMENT PLANTS

Daniel C, Talbot PJ (1987) Physico-chemical properties of murine hepatitis virus, strain A59. Arch Virol 96:241-248. https://doi.org/10. 1007/BF01320963

Daughton CG (2018) Monitoring wastewater for assessing community health: Sewage Chemical-Information Mining (SCIM). Sci Total Environ 619:748-764. https://doi.org/10.1016/j.scitotenv.2017.11. 102

Daughton C (2020) The international imperative to rapidly and inexpensively monitor community-wide Covid-19 infection status and trends. Sci Total Environ 726:138149. https://doi.org/10.1016/j. scitotenv.2020.138149

Demeke T, Jenkins GR (2010) Influence of DNA extraction methods, PCR inhibitors and quantification methods on real-time PCR assay of biotechnology-derived traits. Anal Bioanal Chem 396(6):19771990. https://doi.org/10.1007/s00216-009-3150-9

Designated Best Use Water Quality Criteria (Water Quality Criteria, CPCB India) (2020) https://cpcb.nic.in/wqm/Designated_Best Use_Water_Quality_Criteria.pdf. Accessed 04 Apr 2020

Drosten C, Seilmaier M, Corman VM, Hartmann W, Scheible G, Sack S, Guggemos W, Kallies R, Muth D, Junglen S, Müller MA (2013) Clinical features and virological analysis of a case of Middle East respiratory syndrome coronavirus infection. Lancet Infect Dis 13(9): 745-751. https://doi.org/10.1016/S1473-3099(13)70154-3

Duan SM, Zhao XS, Wen RF, Huang JJ, Pi GH, Zhang SX, Han J, Bi SL, Ruan L, Dong XP (2003) Stability of SARS coronavirus in human specimens and environment and its sensitivity to heating and UV 
irradiation. Biomed Environ Sci BES 16(3):246-255 https:// www.ncbi.nlm.nih.gov/pubmed/ 14631830

Egyir B, Obeng-Nkrumah N, Kyei GB (2020) COVID-19 pandemic and antimicrobial resistance: another call to strengthen laboratory diagnostic capacity in Africa. Afr J Lab Med 9(1):a1302. https://doi.org/ 10.4102/ajlm.v9i1.1302

ENVIS Centre on hygiene, sanitation, sewage treatment systems and technology, Govt. of India 2019 National Status of Waste Water Generation \& Treatment http://www.sulabhenvis.nic.in/Database/ STST_wastewater_2090.aspx. Accessed 06 April 2020)

Farkas K, McDonald JE, Malham SK, Jones DL (2018) Two-step concentration of complex water samples for the detection of viruses. Methods Protocols 1(3):35. https://doi.org/10.3390/mps1030035

Foladori P, Cutrupi F, Segata N, Manara S, Pinto F, Malpei F, Bruni L, La Rosa G (2020) SARS-CoV-2 from faeces to wastewater treatment: What do we know? A review. Science of the Total Environment, $\mathrm{p}$ 140444. https://doi.org/10.1016/j.scitotenv.2020.140444

Fumian TM, Leite JPG, Castello AA, Gaggero A, de Caillou MSL, Miagostovich MP (2010) Detection of rotavirus A in sewage samples using multiplex qPCR and an evaluation of the ultracentrifugation and adsorption-elution methods for virus concentration. J Virol Methods 170(1-2):42-46. https://doi.org/10.1016/j.jviromet.2010. 08.017

Gerrity D, Papp K, Stoker M et al (2021) Early-pandemic wastewater surveillance of SARS-CoV-2 in Southern Nevada : methodology , occurrence, and incidence / prevalence considerations. Water Res X 10:100086. https://doi.org/10.1016/j.wroa.2020.100086

Giri AK, Rana DR (2020) Charting the challenges behind the testing of COVID-19 in developing countries: Nepal as a case study. https:// doi.org/10.1016/j.bsheal.2020.05.002

Golovko O, Kumar V, Fedorova G, Randak T, Grabic R (2014) Seasonal changes in antibiotics, antidepressants/psychiatric drugs, antihistamines and lipid regulators in a wastewater treatment plant. Chemosphere 111:418-426. https://doi.org/10.1016/j. chemosphere.2014.03.132

Gonzalez R, Curtis K, Bivins A et al (2020) COVID-19 surveillance in Southeastern Virginia using wastewater-based epidemiology. Water Res 186:116296. https://doi.org/10.1016/j.watres.2020.116296

Gormley M, Aspray TJ, Kelly DA, Rodriguez-Gil C (2017) Pathogen cross - transmission via building sanitary plumbing systems in a full-scale pilot test-rig. PLoS One 12(2):1-13. https://doi.org/10. 1371/journal.pone.0171556

Gormley M, Aspray TJ, Kelly DA (2020) COVID-19: Mitigating transmission via wastewater plumbing systems. Lancet Glob Health 20: 30112. https://doi.org/10.1016/S2214-109X(20)30112-1

Gourinat AC, O'Connor O, Calvez E et al (2015) Detection of zika virus in urine. Emerg Infect Dis 21:84-86. https://doi.org/10.3201/ eid2101.140894

Gu J, Han B, Wang J (2020) COVID-19: gastrointestinal manifestations and potential fecal-oral transmission. Gastroenterology 158(6): 1518-1519. https://doi.org/10.1053/j.gastro.2020.02.054

Guerra P, Kim M, Shah A et al (2014) Occurrence and fate of antibiotic, analgesic/anti-inflammatory, and antifungal compounds in five wastewater treatment processes. Sci Total Environ 473-474:235243. https://doi.org/10.1016/j.scitotenv.2013.12.008

Guerrero-Latorre L, Ballesteros I, Villacrés IM, Granda MG, FreirePaspuel B, Ríos-Touma B (2020) SARS-CoV-2 in river water: Implications in low sanitation countries. Sci Total Environ 140832. https://doi.org/10.1016/j.scitotenv.2020.140832

Gundy PM, Gerba CP, Pepper IL (2009) Survival of coronaviruses in water and wastewater. Food Environ Virol 1(1):10-14. https://doi. org/10.1007/s12560-008-9001-6

Haagmans BL, Al Dhahiry SH, Reusken CB, Raj VS, Galiano M, Myers R, Godeke GJ, Jonges M, Farag E, Diab A, Ghobashy H (2014) Middle East respiratory syndrome coronavirus in dromedary camels: an outbreak investigation. Lancet Infect Dis 14(2):140 145. https://doi.org/10.1016/S1473-3099(13)70690-X

Han H, Luo Q, Mo F, Long L, Zheng W (2020) SARS-CoV-2 RNA more readily detected in induced sputum than in throat swabs of convalescent COVID-19 patients. Lancet Infect Dis 20(6):655-656. https://doi.org/10.1016/S1473-3099(20)30174-2

Haramoto E, Kitajima M, Katayama H, Ito T, Ohgaki S (2009) Development of virus concentration methods for detection of koi herpesvirus in water. J Fish Dis 32(3):297-300. https://doi.org/10. 1111/j.1365-2761.2008.00977.x

Haramoto E, Malla B, Thakali O, Kitajima M (2020a) First environmental surveillance for the presence of SARS-CoV-2 RNA in wastewater and river water in Japan. Sci Total Environ 737:140405. https:// doi.org/10.1016/j.scitotenv.2020.140405

Haramoto E, Malla B, Thakali O, Kitajima M (2020b) Science of the total environment first environmental surveillance for the presence of SARS-CoV-2 RNA in wastewater and river water in Japan. Sci Total Environ 737:140405. https://doi.org/10.1016/j.scitotenv. 2020.140405

Hart OE, Halden RU (2020) Computational analysis of SARS-CoV-2/ COVID-19 surveillance by wastewater-based epidemiology locally and globally: feasibility, economy, opportunities and challenges. Sci Total Environ 730:138875. https://doi.org/10.1016/j.scitotenv.2020. 138875

Heller L, Mota CR, Greco DB (2020) COVID-19 faecal-oral transmission: are we asking the right questions? Sci Total Environ:138919. https://doi.org/10.1016/j.scitotenv.2020.138919

Hellmér M, Paxéus N, Magnius L et al (2014) Detection of pathogenic viruses in sewage provided early warnings of hepatitis A virus and norovirus outbreaks. Appl Environ Microbiol 80:6771-6781. https://doi.org/10.1128/AEM.01981-14

Hijosa-Valsero M, Fink G, Schlüsener MP et al (2011) Removal of antibiotics from urban wastewater by constructed wetland optimization. Chemosphere 83:713-719. https://doi.org/10.1016/j.chemosphere. 2011.02.004

Hindson J (2020) COVID-19: faecal-oral transmission. Nat Rev Gastroenterol Hepatol 17(5):259-259. https://doi.org/10.1038/ s41575-020-0295-7

Holshue ML, DeBolt C, Lindquist S, Lofy KH, Wiesman J, Bruce H, Spitters C, Ericson K, Wilkerson S, Tural A, Diaz G, Cohn A, Fox LA, Patel A, Gerber SI, Kim L, Tong S, Lu X, Lindstrom S, Pallansch MA, Weldon WC, Biggs HM, Uyeki TM, Pillai SK (2020) First case of 2019 novel coronavirus in the United States. N Eng1 J Med 382:929-936. https://doi.org/10.1056/ NEJMoa2001191

Huang Y, Zhao N (2020) Generalized anxiety disorder, depressive symptoms and sleep quality during COVID-19 outbreak in China: a webbased cross-sectional survey. Psychiatry Res 112954. https://doi. org/10.1016/j.psychres.2020.112954

Huang Q, Yu Y, Tang C, Peng X (2010) Determination of commonly used azole antifungals in various waters and sewage sludge using ultra-high performance liquid chromatography - tandem mass spectrometry. J Chromatogr A 1217:3481-3488. https://doi.org/10. 1016/j.chroma.2010.03.022

Huang C, Wang Y, Li X, Ren L, Hu Y, Zhang L, Fan G, Xu J, Gu X, Cheng Z, Yu T, Xia J, Wei Y, Wu W, Xie X, Yin W, Li H, Liu M, Xiao Y, Gao H, Guo L, Xie J, Wang G, Jiang R, Gao Z, Jin Q, Wang J, Cao B (2020) Clinical features of patients infected with 2019 novel coronavirus in Wuhan, China. Lancet 395(10223):497-506. https://doi.org/10.1016/S0140-6736(20)30183-5

Imai M, Ninomiya A, Minekawa H, Notomi T, Ishizaki T, Van Tu P, Tien NTK, Tashiro M, Odagiri T (2007) Rapid diagnosis of H5N1 avian influenza virus infection by newly developed influenza $\mathrm{H} 5$ hemagglutinin gene-specific loop-mediated isothermal amplification method. J Virol Methods 141:173-180. https://doi.org/10.1016/j. jviromet.2006.12.004 
Jumat MR, Hasan NA, Subramanian P, Heberling C, Colwell RR, Hong PY (2017) Membrane bioreactor-basedwastewater treatment plant in Saudi Arabia: Reduction of Viral Diversity, Load, and Infectious Capacity. Water (Switzerland) 9(7). https://doi.org/10.3390/ w9070534

Jung YJ, Park GS, Moon JH, Ku K, Beak SH, Kim S, Park EC, Park D, Lee JH, Byeon CW, Lee JJ (2020) Comparative analysis of primerprobe sets for the laboratory confirmation of SARS-CoV-2. BioRxiv. https://doi.org/10.1101/2020.02.25.964775

Kampf G, Todt D, Pfaender S, Steinmann E (2020) Persistence of coronaviruses on inanimate surfaces and their inactivation with biocidal agents. J Hosp Infect 104:246-251. https://doi.org/10.1016/j. jhin.2020.01.022

Kasprzyk-Hordern B, Dinsdale RM, Guwy AJ (2009) The removal of pharmaceuticals, personal care products, endocrine disruptors and illicit drugs during wastewater treatment and its impact on the quality of receiving waters. Water Res 43:363-380. https://doi.org/10. 1016/j.watres.2008.10.047

Kasprzyk-Hordern B, Bijlsma L, Castiglioni S, Covaci A, de Voogt P, Emke E, Hernandez F, Ort C, Reid M, van Nuijs A, Thomas KV (2014) Wastewater-based epidemiology for public health monitoring. Water Sewerage J 4:25-26

Kataki S, Chatterjee S, Vairale MG, Sharma S, Dwivedi SK (2020) Concerns and strategies for wastewater treatment during COVID19 pandemic to stop plausible transmission. Resour Conserv Recycl 105156. https://doi.org/10.1016/j.resconrec.2020.105156

Katayama H, Haramoto E, Oguma K, Yamashita H, Tajima A, Nakajima H, Ohgaki S (2008) One-year monthly quantitative survey of noroviruses, enteroviruses, and adenoviruses in wastewater collected from six plants in Japan. Water Res 42(6-7):1441-1448. https:// doi.org/10.1016/j.watres.2007.10.029

Kavanagh MM, Erondu NA, Tomori O, Dzau VJ, Okiro EA, Maleche A, Aniebo IC, Rugege U, Holmes CB, Gostin LO (2020) Access to lifesaving medical resources for African countries: COVID-19 testing and response, ethics, and politics. Lancet 395(10238):17351738. https://doi.org/10.1016/S0140-6736(20)31093-X

Kellner MJ, Koob JG, Gootenberg JS, Abudayyeh OO, Zhang F (2019) SHERLOCK: nucleic acid detection with CRISPR nucleases. Nat Protoc 14:2986-3012. https://doi.org/10.1038/s41596-019-0210-2

Kim J, Biondi MJ, Feld JJ, Chan WCW (2016) Clinical validation of quantum dot barcode diagnostic technology. ACS Nano 10:47424753. https://doi.org/10.1021/acsnano.6b01254

Kitajima M, Ahmed W, Bibby K, Carducci A, Gerba CP, Hamilton KA, Haramoto E, Rose JB (2020) SARS-CoV-2 in wastewater: state of the knowledge and research needs. Sci Total Environ 139076. https://doi.org/10.1016/j.scitotenv.2020.139076

Kretchy IA, Asiedu-Danso M, Kretchy JP (2020) Medication management and adherence during the COVID-19 pandemic: Perspectives and experiences from LMICs. Res Soc Adm Pharm. https://doi.org/ 10.1016/j.sapharm.2020.04.007

Kumar M, Patel AK, Shah AV, Raval J, Rajpara N, Joshi M Joshi CG, (2020a) First proof of the capability of wastewater surveillance for COVID-19 in India through detection of genetic material of SARSCoV-2. Sci Total Environ 141326. https://doi.org/10.1016/j. scitotenv.2020.141326

Kumar M, Taki K, Gahlot R, Sharma A, Dhangar K, (2020b) A chronicle of SARS-CoV-2: Part-I-Epidemiology, diagnosis, prognosis, transmission and treatment. Sci Total Environ 139278. https://doi.org/10. 1016/j.scitotenv.2020.139278

Kumar M, Kuroda K, Dhangar K, Mazumder P, Sonne C, Rinklebe J, Kitajima M (2020c) Potential emergence of antiviral-resistant pandemic viruses via environmental drug exposure of animal reservoirs. Environ Sci Technol 54:8503-8505

La Rosa G, Bonadonna L, Lucentini L, Kenmoe S, Suffredini E (2020) Coronavirus in water environments: Occurrence, persistence and concentration methods - a scoping review. Water Res 179: 115899. https://doi.org/10.1016/j.watres.2020.115899

Lai CC, Liu YH, Wang CY, Wang YH, Hsueh SC, Yen MY, Ko WC, Hsueh PR (2020) Asymptomatic carrier state, acute respiratory disease, and pneumonia due to severe acute respiratory syndrome coronavirus 2 (SARSCoV-2): facts and myths. J Microbiol Immunol Infect. https://doi.org/10.1016/j.jmii.2020.02.012

Laksanasopin T, Guo TW, Nayak S, Sridhara AA, Xie S, Olowookere OO, Cadinu P, Meng F, Chee NH, Kim J, Chin CD, Munyazesa E, Mugwaneza P, Rai AJ, Mugisha V, Castro AR, Steinmiller D, Linder V, Justman JE, Nsanzimana S, Sia SK (2015) A smartphone dongle for diagnosis of infectious diseases at the point of care. Sci Transl Med 7:273re1. https://doi.org/10.1126/scitranslmed.aaa0056

Lee N, Yuen KY, Sung JJY (2003) Enteric involvement of severe acute respiratory syndrome-associated coronavirus infection. Gastroenterology 125(04):1011-1017. https://doi.org/10.1016/j. gastro.2003.08.001

Leknes H, Sturtzel IE, Dye C (2012) Environmental release of oseltamivir from a Norwegian sewage treatment plant during the 2009 influenza A (H1N1) pandemic. Sci Total Environ 414:632-638. https://doi. org/10.1016/j.scitotenv.2011.11.004

Lin L, Jiang X, Zhang Z, Huang S, Zhang Z, Fang Z, Gu Z, Gao L, Shi H, Mai L, Liu Y (2020) Gastrointestinal symptoms of 95 cases with SARS-CoV-2 infection. Gut 69(6):997-1001. https://doi.org/10. 1136/gutjnl-2020-321013

Ling Y, Xu SB, Lin YX, Tian D, Zhu ZQ, Dai FH, Wu F, Song ZG, Huang W, Chen J, Hu BJ, Wang S, Mao EQ, Zhu L, Zhang WH, Lu HZ (2020) Persistence and clearance of viral RNA in 2019 novel coronavirus disease rehabilitation patients. Chin Med J 133(9): 1039-1043. https://doi.org/10.1097/CM9.0000000000000774

Liu Y, Ning Z, Chen Y, Guo M, Liu Y, Gali NK, Liu X (2020) Aerodynamic analysis of SARS-CoV-2 in two Wuhan hospitals. Nature 582(7813):557-560. https://doi.org/10.1038/s41586-0202271-3

Lodder W, de Roda Husman AM (2020) SARS-CoV-2 in wastewater: potential health risk, but also data source. Lancet Gastroenterol Hepatol 5:533-534. https://doi.org/10.1016/S2468-1253(20) 30087-X

Lozano N, Rice CP, Ramirez M, Torrents A (2013) Fate of triclocarban, triclosan and methyltriclosan during wastewater and biosolids treatment processes. Water Res 47(13):4519-4527. https://doi.org/10. 1016/j.watres.2013.05.015

Macherius A, Eggen T, Lorenz W, Moeder M, Ondruschka J, Reemtsma T (2012) Metabolization of the bacteriostatic agent triclosan in edible plants and its consequences for plant uptake assessment. Environ Sci Technol 46:10797-10804. https://doi.org/10.1021/es3028378

Maillard JY, Bloomfield SF, Courvalin P et al (2020) Reducing antibiotic prescribing and addressing the global problem of antibiotic resistance by targeted hygiene in the home and everyday life settings: a position paper. Am J Infect Control 48:1090-1099. https://doi.org/ 10.1016/j.ajic.2020.04.011

Mao K, Zhang H, Yang Z (2020a) An integrated biosensor system with mobile health and wastewater-based epidemiology (iBMW) for COVID-19 pandemic. Biosens Bioelectron 169:112617

Mao K, Zhang H, Yang Z (2020b) Can a paper-based device trace COVID-19 sources with wastewater-based epidemiology? Environ Sci Technol 54:3733-3735. https://doi.org/10.1021/acs.est.0c01174

Mao K, Zhang K, Du W et al (2020c) The potential of wastewater-based epidemiology as surveillance and early warning of infectious disease outbreaks. Curr Opin Environ Sci Health 17:1-7. https://doi.org/10. 1016/j.coesh.2020.04.006

Mariani A, Bonfio C, Johnson CM, Sutherland JD (2018) PH-Driven RNA strand separation under prebiotically plausible conditions. Biochemistry 57:6382-6386. https://doi.org/10.1021/acs.biochem. 8 b01080 
Martel N, Gomes SA, Chemin I, Trépo C, Kay A (2013) Improved rolling circle amplification (RCA) of hepatitis B virus (HBV) relaxedcircular serum DNA (RC-DNA). J Virol Methods 193:653-659. https://doi.org/10.1016/j.jviromet.2013.07.045

Medema G, Been F, Heijnen L, Petterson S (2020a) Implementation of environmental surveillance for SARS-CoV-2 virus to support public health decisions: Opportunities and challenges. Curr Opin Environ Sci Health 17:49-71. https://doi.org/10.1016/j.coesh.2020.09.006

Medema G, Heijnen L, Elsinga G, Italiaander R, Brouwer A (2020b) Presence of SARS-Coronavirus-2 RNA in sewage and correlation with reported COVID-19 prevalence in the early stage of the epidemic in the Netherlands. Environ Sci Technol Lett. https://doi.org/ 10.1021/acs.estlett.0c00357

Michael-Kordatou I, Karaolia P, Fatta-Kassinos D (2020) Sewage analysis as a tool for the COVID-19 pandemic response and management: the urgent need for optimised protocols for SARS-CoV-2 detection and quantification. J Environ Chem Eng 8:104306. https://doi.org/10.1016/j.jece.2020.104306

Mumy KL, Findlay RH (2004) Convenient determination of DNA extraction efficiency using an external DNA recovery standard and quantitative-competitive PCR. J Microbiol Methods 57(2):259268. https://doi.org/10.1016/j.mimet.2004.01.013

Naddeo V, Liu H (2019) Editorial perspectives: 2019 novel coronavirus (SARS-CoV-2): what is its fate in urban water cycle and how can the water research community respond? Environ Sci: Water Res Technol 6:1213-1216. https://doi.org/10.1039/D0EW90015J

Nakamura T, Hamasaki M, Yoshitomi H, Ishibashi T, Yoshiyama C, Maeda E, Sera N, Yoshida H (2015) Environmental surveillance of poliovirus in sewage water around the introduction period for inactivated polio vaccine in Japan. Appl Environ Microbiol 81(5): 1859-1864. https://doi.org/10.1128/AEM.03575-14

National River Conservation Plan (NRCP), National River Conservation Directorate, Ministry of Jal Shakti Department of Water Resources, River Development \&amp; Ganga Rejuvenation, Government of India, 2020 (https://nrcd.nic.in/writereaddata/FileUpload/ 10291455nrcd_B.pdf) (Accessed on August 07, 2020)

National Statistical Office (2019) Drinking water, sanitation, hygiene and housing conditions in India

Nemudryi A, Nemudraia A, Surya K, Wiegand T, Buyukyoruk M, Wilkinson R, Wiedenheft B (2020) Temporal detection and phylogenetic assessment of SARS-CoV-2 in municipal wastewater. medRxiv. https://doi.org/10.1101/2020.04.15.20066746

Nilsson HO, Aleljung P, Nilsson I, Tyszkiewicz T, Wadström T (1996) Immunomagnetic bead enrichment and PCR for detection of Helicobacter pylori in human stools. J Microbiol Methods 27:7379. https://doi.org/10.1016/0167-7012(96)00930-X

Nomoto H, Ishikane M, Katagiri D, Kinoshita N, Nagashima M, Sadamasu K, Yoshimura K, Ohmagari N (2020) Cautious handling of urine from moderate to severe COVID-19 patients. Am J Infect Control. https://doi.org/10.1016/j.ajic.2020.05.034

Núñez-Delgado A (2020) What do we know about the SARS-CoV-2 coronavirus in the environment? Sci Total Environ 138647. https://doi.org/10.1016/j.scitotenv.2020.138647

O'Brien E, Xagoraraki I (2019) A water-focused one-health approach for early detection and prevention of viral outbreaks. One Health 7: 100094. https://doi.org/10.1016/j.onehlt.2019.100094

Olaniyan LWB, Mkwetshana N, Okoh AI (2016) Triclosan in Water, Implications for Human and Environmental Health. Springerplus 5(1). https://doi.org/10.1186/s40064-016-3287-x

Oliver MMH, Hewa GA, Pezzaniti D, Haque MA, Haque S, Haque MM, Moniruzzaman M, Rahman MM, Saha KK, Kadir MN (2020) COVID-19 and recycled wastewater irrigation: a review of implications. https://doi.org/10.20944/preprints202006.0105.v1

Orive G, Lertxundi U, Barcelo D (2020) Early SARS-CoV-2 outbreak detection by sewage-based epidemiology. Sci Total Environ 139298. https://doi.org/10.1016/j.scitotenv.2020.139298
OSHA, Standards and directives for COVID-19 (2020) United States of America Occupational Safety and Health Administration. https:// www.osha.gov/SLTC/covid-19/standards.html, 2020. Accessed 04 June 2020

Otter JA, Donskey C, Yezli S, Douthwaite S, Goldenberg SD, Weber DJ (2016) Transmission of SARS and MERS coronaviruses and influenza virus in healthcare settings: the possible role of dry surface contamination. J Hosp Infect 92:235-250. https://doi.org/10.1016/ j.jhin.2015.08.027

Pandey D, Verma S, Verma P et al (2021) SARS-CoV-2 in wastewater: challenges for developing countries. Int J Hyg Environ Health 231: 113634. https://doi.org/10.1016/j.ijheh.2020.113634

Paull DH, Halden RU (2005) Co-occurrence of triclocarban and triclosan in U. S. water resources. Environ Sci Technol 39:1420-1426. https://doi.org/10.1021/es049071e

Polo D, Quintela-baluja M, Corbishley A et al (2020) Making waves: wastewater-based epidemiology for COVID-19-approaches and challenges for surveillance and prediction. Water Res 186:116404. https://doi.org/10.1016/j.watres.2020.116404

Purnell S, Ebdon J, Buck A, Tupper M, Taylor H (2016) Removal of phages and viral pathogens in a full-scale MBR: implications for wastewater reuse and potable water. Water Res 100:20-27. https:// doi.org/10.1016/j.watres.2016.05.013

Pycke BFG, Roll IB, Brownawell BJ, Kinney CA, Furlong ET, Kolpin DW, Halden RU (2014) Transformation products and human metabolites of triclocarban and triclosan in sewage sludge across the United States. Environ Sci Technol 48:7881-7890. https://doi.org/ 10.1021/es5006362

Qiu Y, Lee BE, Neumann N, Ashbolt N, Craik S, Maal-Bared R, Pang XL (2015) Assessment of human virus removal during municipal wastewater treatment in Edmonton, Canada. J Appl Microbiol 119(6):1729-1739. https://doi.org/10.1111/jam.12971

Randazzo W, Truchado P, Cuevas-Ferrando E, Simón P, Allende A, Sánchez G (2020) SARS-CoV-2 RNA in wastewater anticipated COVID-19 occurrence in a low prevalence area. Water Res 115942. https://doi.org/10.1016/j.watres.2020.115942

Rawson TM, Ming D, Ahmad R, Moore LS, Holmes AH (2020) Antimicrobial use, drug-resistant infections and COVID-19. Nat Rev Microbiol:1-2. https://doi.org/10.1038/s41579-020-0395-y

RICE. Changes in open defecation in rural north India: 2014-2018. Research Institute for Compassionate Economics. 2019. Available at: https://riceinstitute.org/research/changes-in-open-defecation-inrural-north-india-2014-2018-2/

Rice J, Kasprzyk-Hordern B (2019) A new paradigm in public health assessment: water fingerprinting for protein markers of public health using mass spectrometry. TrAC Trends Anal Chem 119:115621. https://doi.org/10.1016/j.trac.2019.115621

Rimoldi SG, Stefani F, Gigantiello A, Polesello S, Comandatore F, Mileto D, Maresca M, Longobardi C, Mancon A, Romeri F, Pagani C (2020) Presence and vitality of SARS-CoV-2 virus in wastewaters and rivers. medRxiv. https://oi.org/10.1101/2020.05. 01.20086009

Rissin DM, Kan CW, Campbell TG, Howes SC, Fournier DR, Song L, Piech T, Patel PP, Chang L, Rivnak AJ, Ferrell EP, Randall JD, Provuncher GK, Walt DR, Duffy DC (2010) Single-molecule enzyme-linked immunosorbent assay detects serum proteins at subfemtomolar concentrations. Nat Biotechnol 28:595-599. https://doi.org/10.1038/nbt.1641

Rose C, Parker A, Jefferson B, Cartmell E (2015) The characterization of feces and urine: a review of the literature to inform advanced treatment technology. Crit Rev Environ Sci Technol 45(17):1827-1879. https://doi.org/10.1080/10643389.2014.1000761

Rothe C, Schunk M, Sothmann P, Bretzel G, Froeschl G, Wallrauch C, Zimmer T, Thiel V, Janke C, Guggemos W, Seilmaier M (2020) Transmission of 2019-nCoV infection from an asymptomatic contact in Germany. N Engl J Med 382(10):970-971 
Rowe T, Abernathy RA, Hu-Primmer J, Thompson WW, Lu X, Lim W, Fukuda K, Cox NJ, Katz JM (1999) Detection of antibody to avian influenza a $(\mathrm{H} 5 \mathrm{~N} 1)$ virus in human serum by using a combination of serologic assays. J Clin Microbiol 37:937-943. https://doi.org/10. 1128/jcm.37.4.937-943.1999

Saawarn B, Hait S (2021) Occurrence, fate and removal of SARS-CoV-2 in wastewater: Current knowledge and future perspectives. J Environ Chem Eng 9:104870

Schaub SA, Sorber CA, Taylor GW, Lefler E, Kott Y, Malina JF, Ranganathan KR, Moore BE, Sagik BP, Nupen EM, Bateman BW (2017) Virus survival in water and wastewater systems. In: Tex Univ, Cent for Res in Water Resour, Symp Ser, no. 7

Senta I, Kostanjevecki P, Krizman-Matasic I et al (2019) Occurrence and behavior of macrolide antibiotics in municipal wastewater treatment: possible importance of metabolites, synthesis byproducts, and transformation products. Environ Sci Technol 53:7463-7472. https://doi.org/10.1021/acs.est.9b01420

Shannon KE, Lee DY, Trevors JT, Beaudette LA (2007) Application of real-time quantitative PCR for the detection of selected bacterial pathogens during municipal wastewater treatment. Sci Total Environ 382:121-129. https://doi.org/10.1016/j.scitotenv.2007.02. 039

Shirato K, Nishimura H, Saijo M, Okamoto M, Noda M, Tashiro M, Taguchi F (2007) Diagnosis of human respiratory syncytial virus infection using reverse transcription loop-mediated isothermal amplification. J Virol Methods 139:78-84. https://doi.org/10.1016/j. jviromet.2006.09.014

Silverman AI, Boehm AB (2020) Systematic review and meta-analysis of the persistence and disinfection of human coronaviruses and their viral surrogates in water and wastewater. Environ Sci Technol Lett. https://doi.org/10.1021/acs.estlett.0c00313

Sims N, Kasprzyk-Hordern B (2020) Future perspectives of wastewaterbased epidemiology: monitoring infectious disease spread and resistance to the community level. Environ Int 105689. https://doi.org/ 10.1016/j.envint.2020.105689

Simpson B (2013) Wastewater Sampling. U S Environ Prot Agency 124. https://www.epa.gov/sites/production/files/2015-06/documents/ Wastewater-Sampling.pdf

Sinclair RG, Choi CY, Riley MR, Gerba CP (2008) Pathogen surveillance through monitoring of sewer systems. Adv Appl Microbiol 65: 249-269. https://doi.org/10.1016/S0065-2164(08)00609-6

Slater FR, Singer AC, Turner S, Barr JJ, Bond PL (2011) Pandemic pharmaceutical dosing effects on wastewater treatment: no adaptation of activated sludge bacteria to degrade the antiviral drug Oseltamivir (Tamifluß) and loss of nutrient removal performance. FEMS Microbiol Lett 315(1):17-22. https://doi.org/10.1111/j.15746968.2010.02163.x

Street R, Malema S, Mahlangeni N, Mathee A (2020) Wastewater surveillance for Covid-19: An African perspective. Sci Total Environ 743:140719. https://doi.org/10.1016/j.scitotenv.2020.140719

Stuveling EM, Hillege HL, Bakker SJL et al (2003) C-reactive protein is associated with renal function abnormalities in a non-diabetic population. Kidney Int 63:654-661. https://doi.org/10.1046/j.15231755.2003.00762.x

Sun, S., \& Han, J. 2020. Open defecation and squat toilets, an overlooked risk of fecal transmission of COVID-19 and other pathogens in developing communities. Environ Chem Lett 1-9. https://doi.org/ 10.1007/s10311-020-01143-1

Sung H, Yong D, Ki CS, Kim JS, Seong MW, Lee H, Kim MN (2016) Comparative evaluation of three homogenization methods for isolating Middle East respiratory syndrome coronavirus nucleic acids from sputum samples for real-time reverse transcription PCR. Ann Lab Med 36(5):457-462. https://doi.org/10.3343/alm.2016.36.5. 457

Taha AS, Grant V, Kelly RW (2003) Urinalysis for interleukin-8 in the non-invasive diagnosis of acute and chronic inflammatory diseases.
Postgrad Med J 79:159-163. https://doi.org/10.1136/pmj.79.929. 159

Takanami R, Ozaki H, Giri RR et al (2012) Antiviral Drugs Zanamivir and Oseltamivir Found in wastewater and surface water in Osaka, Japan. J Water Environ Technol 10:57-68. https://doi.org/10.2965/ jwet.2012.57

Tang A, Tong ZD, Wang HL, Dai YX, Li KF, Liu JN, Wu WJ, Yuan C, Yu ML, Li P, Yan JB (2020) Detection of novel coronavirus by RTPCR in stool specimen from asymptomatic child, China. Emerg Infect Dis 26(6):1337-1339. https://doi.org/10.3201/eid2606. 200301

Thaxton CS, Elghanian R, Thomas AD, Stoeva SI, Lee JS, Smith ND, Schaeffer AJ, Klocker H, Horninger W, Bartsch G, Mirkin CA (2009) Nanoparticle-based bio-barcode assay redefines "undetectable" PSA and biochemical recurrence after radical prostatectomy. Proc Natl Acad Sci U S A 106:18437-18442. https://doi.org/10. 1073/pnas.0904719106

Thompson JR, Nancharaiah YV, Gu X, Lee WL, Rajal VB, Haines MB, Girones R, Ng LC, Alm EJ, Wuertz S (2020) Making waves: wastewater surveillance of SARS-CoV-2 for population-based health management. Water Res. 116181. https://doi.org/10.1016/j.watres. 2020.116181

UNESCO (2020) How soap kills COVID-19 on hands. https://en.unesco. org/news/how-soap-kills-covid-19-hands. Accessed 06 August 2020

UN World Water Development Report (WWDR) (2017). https://www. unwater.org/publications/world-water-development-report-2017/. Accessed 04 Nov 2020

United Nations World Water Assessment Programme (2017) The United Nations World Water Development Report 2017. Wastewater: The Untapped Resource. Paris: UNESCO.

Usman M, Farooq M, Hanna K (2020a) Environmental side effects of the injudicious use of antimicrobials in the era of COVID-19. Sci Total Environ:141053. https://doi.org/10.1016/j.scitotenv.2020.141053

Usman M, Farooq M, Hanna K (2020b) Existence of SARS-CoV-2 in wastewater: implications for its environmental transmission in developing communities. (54):7758-7759. https://doi.org/10.1021/ acs.est.0c02777

van Doremalen N, Bushmaker T,Morris DH (2020) Aerosol and surface stability of SARS-CoV-2 as compared with SARS-CoV-1. N Engl J Med 0-3. https://doi.org/10.1056/NEJMc2004973

Vogels CB, Brito AF, Wyllie AL, Fauver JR, Ott IM, Kalinich CC, Petrone ME, Landry ML, Foxman EF, Grubaugh ND, (2020) Analytical sensitivity and efficiency comparisons of SARS-COV-2 qRT-PCR assays. medRxiv. https://doi.org/10.1101/2020.03.30. 20048108

Wang XW, Li JS, Jin M, Zhen B, Kong QX, Song N, Xiao WJ, Yin J, Wei W, Wang GJ, Si BY, Guo BZ, Liu C, Ou GR, Wang MN, Fang TY, Chao FH, Li JW (2005) Study on the resistance of severe acute respiratory syndrome-associated coronavirus. J Virol Methods 126(1-2):171-177. https://doi.org/10.1016/j.jviromet.2005.02.005

Wang J, Mao D, Mu Q, Luo Y (2015) Fate and proliferation of typical antibiotic resistance genes in five full-scale pharmaceutical wastewater treatment plants. Sci Total Environ 526:366-373. https://doi. org/10.1016/j.scitotenv.2015.05.046

Wang D, Hu B, Hu C, Zhu F, Liu X, Zhang J, Wang B, Xiang H, Cheng Z, Xiong Y, Zhao Y, Li Y, Wang X, Peng Z (2020a) Clinical characteristics of 138 hospitalized patients with 2019 novel coronavirusinfected pneumonia in Wuhan, China. JAMA - J Am Med Assoc 323(11):1061-1069. https://doi.org/10.1001/jama.2020.1585

Wang X, Xiong E, Tian T, Cheng M, Lin W, Wang H, Zhang G, Sun J, Zhou X (2020b) Clustered regularly interspaced short palindromic repeats/Cas9-mediated lateral flow nucleic acid assay. ACS Nano 14:2497-2508. https://doi.org/10.1021/acsnano.0c00022

Wang W, Xu Y, Gao R, Lu R, Han K, Wu G, Tan W (2020c) Detection of SARS-CoV-2 in different types of clinical specimens. JAMA - J Am 
Med Assoc 323:1843-1844. https://doi.org/10.1001/jama.2020. 3786

Wastewater Treatment Status by Countries and Economies, United 1835 Nations University Institute for Water, Environment and Health 1836 (UNUINWEH) (2019) https://inweh.unu.edu/wastewater1837 treatment-status-by-countries-and-economies/. Accessed 08 1838 August 2020

Wat D, Gelder C, Hibbitts S, Cafferty F, Bowler I, Pierrepoint M, Evans R, Doull I (2008) The role of respiratory viruses in cystic fibrosis. J Cyst Fibros 7:320-328. https://doi.org/10.1016/j.jcf.2007.12.002

Water, sanitation and hygiene (WASH), UNICEF India. https://www. unicef.org/india/what-we-do/water-sanitation-hygiene. Accessed 04 August 2020

WaterAid (2019) Functionality of wastewater treatment plants in lowand middleincome countries. Desk review. WaterAid, London. https://washmatters.wateraid.org/sites/g/files/jkxoof256/files/ functionality-of-wastewater-treatment-plants-in-low\%2D\%2Dandmiddle-income-countries-desk-review 1.pdf. Accessed 08 August 2020

White S, Thorseth AH, Dreibelbis R, Curtis V (2020) The determinants of handwashing behaviour in domestic settings: an integrative systematic review. Int J Hyg Environ Health 227:113512. https://doi.org/ 10.1016/j.ijheh.2020.113512

WHO Consensus document on the epidemiology of severe acute respiratory syndrome (SARS) (2003) World Health Organization. https:// apps.who.int/iris/handle/10665/70863 Accessed 17 June 2020

World Health Organization (2020a) Modes of transmission of virus causing COVID-19: implications for IPC precaution recommendations. https://apps.who.int/iris/handle/10665/331601.Accessed 18 June 2020

World Health Organization (2020b) Water, sanitation, hygiene and waste management for COVID-19. https://apps.who.int/iris/handle/10665/ 331846. Accessed 20 June 2020

World Health Organization (2021) Coronavirus Disease (COVID-19) Dashboard https://covid19.who.int/?gclid=EAIaIQobChMIwpSg Zq87gIV2AorCh3yZQeXEAAYASAAEgLFevD BwE (Accessed 27 January 2021)

Wu Y, Guo C, Tang L, Hong Z, Zhou J, Dong X, Yin H, Xiao Q, Tang Y, Qu X, Kuang L, Fang X, Mishra N, Lu J, Shan H, Jiang G, Huang X (2020a) Prolonged presence of SARS-CoV-2 viral RNA in faecal samples. Lancet Gastroenterol Hepatol 5:434-435. https://doi.org/ 10.1016/S2468-1253(20)30083-2

Wu F, Xiao A, Zhang J, Gu X, Lee WL, Kauffman K, Hanage W, Matus M, Ghaeli N, Endo N, Claire Duvallet, Moniz K, Erickson T, Chai P, Thompson J, Alm E (2020b) SARS-CoV-2 titers in wastewater are higher than expected from clinically confirmed cases. medRxiv. https://doi.org/10.1101/2020.04.05.20051540

Wuhan Municipal Health Commission. Press statement related to novel coronavirus http://wjw.wuhan.gov.cn/front/web/showDetail/ 2020012709194. Accessed 04 April 2020

Wurtzer S, Marechal V, Mouchel JM, Maday Y, Teyssou R, Richard E, Moulin L (2020) Evaluation of lockdown impact on SARS-CoV-2 dynamics through viral genome quantification in Paris wastewaters. medRxiv. https://doi.org/10.1101/2020.04.12.20062679.

Xagoraraki I, O’Brien E (2020) Wastewater-based epidemiology for early detection of viral outbreaks. In: Women in Water Quality. Springer, Cham, pp 75-97. https://doi.org/10.1007/978-3-03017819-2_5
Xiao F, Tang M, Zheng X, Liu Y, Li X, Shan H (2020) Evidence for gastrointestinal infection of SARS-CoV-2. Gastroenterology 158(6):1831-1833. https://doi.org/10.1053/j.gastro.2020.02.055

Xu D, Zhang Z, Jin L, Chu F, Mao Y, Wang H, Liu M, Wang M, Zhang L, Gao GF, Wang FS (2005) Persistent shedding of viable SARS$\mathrm{CoV}$ in urine and stool of SARS patients during the convalescent phase. Eur J Clin Microbiol Infect Dis 24(3):165-171. https://doi. org/10.1007/s10096-005-1299-5

Xu Y, Li X, Zhu B, Liang H, Fang C, Gong Y, Guo Q, Sun X, Zhao D, Shen J, Zhang H (2020) Characteristics of pediatric SARS-CoV-2 infection and potential evidence for persistent fecal viral shedding. Nat Med 26(4):502-505. https://doi.org/10.1038/s41591-020-08174

Yaniv K, Shagan M, Kramarsky-winter E, et al (2020) City-level SARSCoV-2 sewage surveillance

Ye Y, Ellenberg RM, Graham KE, Wigginton KR (2016) Survivability, partitioning, and recovery of enveloped viruses in untreated municipal wastewater. Environ Sci Technol 50(10):5077-5085. https:// doi.org/10.1021/acs.est.6b00876

Zaneti RN, Girardi V, Spilki FR, Mena K, Westphalen APC, da Costa Colares ER, Pozzebon AG, Etchepare RG (2020) QMRA of SARSCoV-2 for workers in wastewater treatment plants. medRxiv. https:// doi.org/10.1101/2020.05.28.20116277

Zhang DX (2020) SARS-CoV-2: air/aerosols and surfaces in laboratory and clinical settings. J Hosp Infect. https://doi.org/10.1016/j.jhin. 2020.05.001

Zhang JC, Wang S, Xue YD (2020a) Fecal specimen diagnosis 2019 novel coronavirus-infected pneumonia. J Med Virol 92:680-682. https://doi.org/10.1002/jmv.25742

Zhang H, Kang Z, Gong H, Xu D, Wang J, Li Z, Cui X, Xiao J, Meng T, Zhou W, Liu J, Xu H (2020b) The digestive system is potential route of 2019-NCov infection: a bioinformatics analysis based on singlecell transcriptomes. bioRxiv 2020, https://doi.org/10.1101/2020.01. 30.927806

Zhang Y, Chen C, Zhu S, Shu C, Wang D, Song J, Song Y, Zhen W, Feng Z, Wu G, Xu J (2020c) Isolation of 2019-nCoV from a stool specimen of a laboratory-confirmed case of the coronavirus disease 2019 (COVID-19). China CDC Weekly 2(8):123-124. https://doi. org/10.46234/ccdcw2020.033

Zhang N, Gong Y, Meng F, Bi Y, Yang P, Wang F (2020d) Virus shedding patterns in nasopharyngeal and fecal specimens of COVID-19 patients. medRxiv. https://doi.org/10.1101/2020.03.28. 20043059

Zheng S, Fan J, Yu F, Feng B, Lou B, Zou Q, Xie G, Lin S, Wang R, Yang X, Chen W, Wang Q, Zhang D, Liu Y, Gong R, Ma Z, Lu S, Xiao Y, Gu Y, Zhang J, Yao H, Xu K, Lu X, Wei G, Zhou J, Fang Q, Cai H, Qiu Y, Sheng J, Chen Y, Liang T 2020 Viral load dynamics and disease severity in patients infected with SARS-CoV-2 in Zhejiang province, China, January-March 2020: retrospective cohort study. Bmj m1443. https://doi.org/10.1136/bmj.m1443

Zhou R, Li F, Chen F, Liu H, Zheng J, Lei C, Wu X (2020) Viral dynamics in asymptomatic patients with COVID-19. Int J Infect Dis. https://doi.org/10.1016/j.ijid.2020.05.030

Publisher's note Springer Nature remains neutral with regard to jurisdictional claims in published maps and institutional affiliations. 